\title{
Who Instigates University-industry Collaborations? University Scientists Versus Firm Employees
}

\author{
Goel, Rajeev K.; Göktepe-Hultén, Devrim; Grimpe, Christoph
}

Document Version

Accepted author manuscript

Published in:

Small Business Economics

DOI:

10.1007/s11187-016-9795-9

Publication date:

2017

License

Unspecified

Citation for published version (APA):

Goel, R. K., Göktepe-Hultén, D., \& Grimpe, C. (2017). Who Instigates University-industry Collaborations? University Scientists Versus Firm Employees. Small Business Economics, 48(3), 503-524.

https://doi.org/10.1007/s11187-016-9795-9

Link to publication in CBS Research Portal

\section{General rights}

Copyright and moral rights for the publications made accessible in the public portal are retained by the authors and/or other copyright owners and it is a condition of accessing publications that users recognise and abide by the legal requirements associated with these rights.

Take down policy

If you believe that this document breaches copyright please contact us (research.lib@cbs.dk) providing details, and we will remove access to the work immediately and investigate your claim. 


\section{Who Instigates University-industry Collaborations?: University Scientists Versus Firm Employees}

\section{Rajeev K. Goel, Devrim Göktepe-Hultén, and Christoph Grimpe}

Journal article (Accepted version)

GITE: Who Instigates University-industry Collaborations? : University Scientists Versus Firm Employees. / Goel, Rajeev K.; Göktepe-Hultén, Devrim; Grimpe, Christoph. In: Small Business Economics, Vol. 48, №. 3, 03.2017, p. 503-524.

The final publication is available at Springer via http://dx.doi.org/10.1007/s11187-016-9795-9

Uploaded to Research@CBS: June २०17 


\title{
Who Instigates University-Industry Collaborations?
}

\section{University Scientists versus Firm Employees}

\author{
Rajeev K. Goel \\ Department of Economics \\ Illinois State University, Normal, IL, USA \\ E-mail: rkgoel@ilstu.edu \\ Devrim Göktepe-Hultén \\ School of Economics and Management \\ Lund University, Sweden \\ E-mail: devrim.goktepe-hulten@fek.lu.se \\ Christoph Grimpe \\ Department of Innovation and Organizational Economics \\ Copenhagen Business School, Denmark \\ E-mail: cg.ino@cbs.dk
}

Published in Small Business Economics, Vol. 48, No. 3, 3.2017, p. 503-524

\begin{abstract}
While evidence on the causes and effects of university-industry interaction is abundant, little is known about how, and particularly by whom, such interaction is instigated in the first place and subsequently managed. In this paper, we investigate which mode of collaboration (joint research, contract research, consulting, in-licensing, or informal contacts) is more likely to be initiated and managed by firm employees versus by university scientists. Moreover, we are interested in the differences between small and large firms to see whether initiation and management are affected by firm size. Using a sample of 833 German manufacturing firms, our results indicate that university scientists typically start collaborations with industry, while firm employees would take over the management of projects. Results vary markedly between small and large firms, with university scientists having somewhat higher difficulties initiating collaborations with large firms than with small firms.
\end{abstract}

Keywords: university-industry collaboration, initiation, management, firm size

JEL: L24, O31 


\title{
Who Instigates University-Industry Collaborations? \\ University Scientists versus Firm Employees
}

\begin{abstract}
While evidence on the causes and effects of university-industry interaction is abundant, little is known about how, and particularly by whom, such interaction is instigated in the first place and subsequently managed. In this paper, we investigate which mode of collaboration (joint research, contract research, consulting, in-licensing, or informal contacts) is more likely to be initiated and managed by firm employees versus by university scientists. Moreover, we are interested in the differences between small and large firms to see whether initiation and management are affected by firm size. Using a sample of 833 German manufacturing firms, our results indicate that university scientists typically start collaborations with industry, while firm employees would take over the management of projects. Results vary markedly between small and large firms, with university scientists having somewhat higher difficulties initiating collaborations with large firms than with small firms.
\end{abstract}

Keywords: university-industry collaboration, initiation, management, firm size

JEL: L24, O31 


\section{Introduction}

It has almost become conventional wisdom that public science constitutes an important ingredient of economic growth and technological progress (Jaffe, 1989; Adams, 1990). In order to benefit from scientific knowledge produced at universities and public research organizations and to improve innovation performance, firms have frequently been shown to establish and maintain collaborative activities with academia (e.g., Cassiman, Veugelers, and Zuniga, 2008). As there are many different channels through which scientific knowledge reaches the private sector (Goel and Rich, 2005; Grimpe and Hussinger, 2013; Antonelli and Link, 2015), most prominently licensing contracts (Jensen and Thursby, 2001; Thursby and Kemp, 2002), joint research (Cockburn and Henderson, 1998) and academic consulting (Jensen, Thursby, and Thursby, 2010), it is important for managers and university administrators alike to assess their relative effectiveness in order to choose the appropriate mode of collaboration for a given research project (D'Este and Patel, 2007; Bozeman, Fay, and Slade, 2013).

Prior research has not examined who initiates university-industry collaboration, and specifically to whom the establishment of joint research projects, contract research, inlicensing, consulting, or informal contacts may be attributed. There are not only qualitative differences among the different modes of collaboration but also differences regarding the intrinsic motivations and reward structures between academia and industry (Goel and Rich, 2005; Steinmo, 2015). For instance, joint research projects involve the sharing of research knowledge and potentially withholding or even banning the publication of research results by academics (Czarnitzki, Grimpe, and Toole, 2015b), while contract research involves only the sharing of pertinent research information. As a result, firm employees and academics may have different preferences for certain types of collaboration and may hence be more likely to initiate certain modes of collaboration compared to others. 
Moreover, prior literature that looks into university-industry interaction from the firm perspective seems to - at least implicitly - assume that these collaborative activities are also managed by the firm (e.g., Köhler, Sofka, and Grimpe, 2012; Grimpe and Hussinger, 2013). While firms may be better able to efficiently manage collaborative research because of existing routines and procedures in industrial research and development (R\&D), particularly those collaborative projects that are publicly funded are oftentimes managed by university scientists (Grimpe, 2012). It is thus unclear which factors actually determine by whom those projects are managed.

Further, our understanding of the role that firm size plays for the initiation and management of university-industry collaboration is fragmented. In the innovation literature, the differential effects of small and large firms date back to the seminal work of Schumpeter (1950) when he argued the advantage of large firms (monopolies) in pursuing and producing new innovations. In fact, firm size (e.g., Fontana, Geuna, and Matt, 2003), firm experience (e.g., Bruneel, D’Este, and Salter, 2010) and age (e.g., Cunningham and Link, 2016) have been shown to be associated with (successful) university-industry collaboration. But a systematic treatment of the role of firm size in initiating and managing relationships with academia is missing in the literature. Hence in this paper, we seek to provide evidence on (a) by whom (i.e., university scientists or firm employees) collaborative projects are initiated and, once initiated, (b) by whom these projects are managed while controlling for project and firm characteristics, and (c) what role firm size plays for initiation and management.

The empirical analysis is based on the German part of the Community Innovation Survey which covers the innovation activities of 833 firms in the manufacturing sector in 2003 and contains information on who initiated and managed collaborative activities with public research institutions. The firms in the sample are representative of different industries and are located throughout Germany. 
We find stark differences among the five formal and informal collaboration modes considered: while individual university scientists turn out to be instrumental in initiating all modes of collaboration, firm R\&D employees are important only for establishing informal contacts. Regarding the management, it turns out that firm employees are more likely to manage more types of collaborative activities than they initiated in the first place. Firms seem to take over the management once the collaboration is established. Moreover, we find noteworthy differences between small and large firms. Larger firms are generally more likely to initiate any form of collaboration compared to smaller firms for which most collaboration is initiated by university scientists. Interestingly, however, small firms are generally much more likely to manage any form of collaboration compared to larger firms. In that sense, our research contributes to the literature on university-industry interaction by shedding new light on the genesis of university-industry relations, a seemingly overlooked area of formal inquiry.

The remainder of this paper is organized as follows. The next two sections will outline the literature background and our framework for analysis. Section 4 will present data, variables and methods while section 5 details the results. We discuss the results and conclude in section 6.

\section{Literature background}

Studies on the interaction between industry and science have touched upon several important phenomena (for an overview see Rothaermel, Agung, and Jiang, 2007), relating to the output of such collaboration (e.g., patents, publications, licensing income, start-up firms), the agents involved in technology commercialization (e.g., technology transfer offices, TTOs), institutional frameworks (e.g., the Bayh-Dole Act), or perceived obstacles of interaction (e.g., Muscio and Vallanti, 2014). Moreover, the different modes of collaboration have been investigated in much detail, distinguishing for example between formal and more informal 
modes (e.g., Goel and Grimpe, 2013; Grimpe and Fier, 2010; Grimpe and Hussinger, 2013). A large body of literature has furthermore looked into the characteristics and motivations of university scientists and firms to engage in collaboration.

There is substantial evidence that certain characteristics of academic scientists are associated with a higher likelihood to be involved with industry (e.g., Link, Siegel, and Bozeman, 2007; Czarnitzki et al., 2015b). Among those characteristics are, for example, the scientist's performance in terms of patent or publication productivity, age, gender, and experience with industry. Another line of research has studied the role of peer effects and the environment in which an academic works as the driver of industry involvement (e.g., Bercovitz and Feldman, 2008; Aschhoff and Grimpe, 2014). Other studies focused on the incentives and motivations of scientists to explain the likelihood to collaborate with industry or rather to be involved in commercial activities (Göktepe-Hultén and Mahagaonkar, 2010).

University research has traditionally been conducted according to the Mertonian norms of science (Merton, 1973; Sauermann and Stephan, 2013). There exists a natural incentive for scientists both to solve the research questions and to disclose. As implied by communalism, the reward for discovery and research should be recognition. A scientist will disclose a discovery as soon as there is sufficient evidence of validity in order to gain recognition and reputation in a timely fashion among the peers. While commercial activities can be a potential source of revenue for universities, it is not clear if scientists will also pursue commercial activities because they may conflict with the universities' institutional logics (Lam, 2015; Steinmo, 2015).

From the firm perspective, several contributions have focused on firm characteristics that are conducive to interacting with public science, especially a firm's absorptive capacity for university knowledge (e.g., Laursen and Salter, 2004; Köhler et al., 2012). Firms are expecting to gain economic benefits, to solve their existing problems or to increase innovative capacity as a result of collaborating with universities or public research organizations. 
Surprisingly, however, while the actual involvement in and content of universityindustry interaction has been the subject of extensive research, the initiation of such projects in the first place has received no attention in prior literature. Moreover, once initiated, collaborations need to be managed in order to yield a productive result. Aside from anecdotal evidence on single projects, no systematic research seems available that explores this aspect of university-industry interaction. In the following, we will therefore focus on firm employees and university scientists as initiators and managers of collaborative activities, drawing a broad distinction between collaborative research, contract research, technology consulting, inlicensing and acquisition of technologies developed at universities, and informal contacts. We will provide arguments for which mode of collaboration is more likely to be associated with firm employees and university scientists in terms of initiation and management, as well as on the role of firm size.

\section{Theoretical framework}

This section discusses the incentives to engage in collaborative relations from the perspectives of the collaborating firm and the university scientist. The bearings of the size of firms on collaborative relations are considered in a second step. Besides developing underlying theoretical arguments and tying to the extant literature, we set up hypotheses that we test in the empirical section. Our arguments revolve around aspects that are associated with potential conflicts in institutional logics between university and industry, an area that has received considerable attention in prior literature on university-industry collaboration (e.g., Bercovitz and Feldman, 2008; Sauermann and Stephan, 2013; Aschhoff and Grimpe, 2014). In this regard, we focus on differences in time horizon, type of research projects, ownership and disclosure of research results, research funding, and the role of peers. ${ }^{1}$

\footnotetext{
${ }^{1}$ These aspects, while not exhaustive, have been motivated in the prior literature cited before. Our choice is also partly dictated by the level of detail in our survey.
} 


\subsection{The perspective of the firm}

Firms increasingly recognize that in order to successfully innovate they oftentimes cannot exclusively rely on their internal $R \& D$ and competence. Collaboration with external partners allows them to access new knowledge and to save R\&D costs (Perkmann and Walsh, 2007; Perkmann and Salter, 2012). Universities are among the external partners that offer high promise, since they allow access to cutting-edge research as well as a pool of talent and skills. University scientists are typically better equipped to tap into interdisciplinary resources and draw fruitful synergies in their research than their counterparts in firms. While some firms perceive university-industry interaction as a pure transfer of technology, university involvement may be helpful during the entire life cycle of firms' innovation projects (Perkmann and Salter, 2012). However, initiating and managing collaborative relations with universities are not easy tasks since they may conflict with firm strategy in several ways:

Time. Due to competitive pressure, firms' main target is oftentimes to manage and complete an innovation project in a timely fashion in order to be able to reap lead time advantages and preempt rivals (Reinganum, 1983, for a review). While academic research, in contrast, normally focuses on long-term challenges and thus may move more slowly, industrial R\&D is driven by time-sensitive product development projects and day-to-day problem solving (Faria, 2005; Perkmann and Salter, 2012).

Basic versus applied research. The nature of research is another important factor. Related to the time concerns, bringing an innovation to the market typically requires applied research and development work as well as quick solutions to upcoming problems (Franzoni, 2009; Libaers, 2012). Academics, in contrast, are rather interested in long-term, basic research questions because only those promise to eventually result in a journal publication which is important for tenure and promotion decisions (Sauermann and Stephan, 2013). On the other hand, research that is susceptible to industrial application allows firms to apply for patent protection. 
Ownership of IP and secrecy. A key element of conflicting institutional logics between academia and industry relates to the handling of research results. The ownership of research results allows appropriation of the fruits of innovation and is a crucial ingredient driving research effort (Teece, 1986). While firms will strive for secrecy in order to not foreclose the opportunity to file for patent protection and hence to increase the appropriability of the returns to an invention, academics are primarily interested in openness in order to facilitate publication and dissemination of research results (Sauermann and Stephan, 2013; Antonelli and Link, 2015). In fact, recent research has shown that industry sponsorship of research projects often entails a delay or even a partial or complete ban to publish research results (Czarnitzki et al., 2015b). In fact, this even extends to research inputs such as data, materials and infrastructure that are less likely to be openly shared in university-industry collaboration (Czarnitzki, Grimpe, and Pellens, 2015a).

Considering all these issues, we expect firms to be more likely to initiate those types of collaborative projects where conflicts related to time, type of research, and IP between academia and industry are less pronounced, i.e. short-term, protected, and applied research projects, which to a higher extent applies to academic consulting, the in-licensing or acquisition of university technology and informal contacts compared to joint and contract research projects. This leads to our first hypothesis:

Hypothesis 1: In-licensing, consulting, and informal contacts are more likely to be initiated by firm employees compared to joint research and contract research.

\subsection{The perspective of the university scientist}

While university scientists, and particularly principal investigators (PI) in research projects, arguably have multi-faceted roles (Boehm and Hogan, 2014; Cunningham et al., 2014; O'Kane et al., 2015), the motivation of individual university scientists to engage with industry 
is often influenced by their values and beliefs about the role of science. Previous research highlights a complex mix of individual-level motives, including social and intrinsic aspects (Lam, 2015). In the traditional Mertonian world of scientific research (Merton, 1973), peer recognition in the form of publications, citations and prizes, namely, the 'ribbon', constitutes the basic form of extrinsic (or social) reward in science from which other extrinsic rewards may be derived, such as career advancement, increase in salaries and enlarged access to research resources. Besides these extrinsic rewards, scientists are also motivated by the intrinsic satisfaction of doing research by solving the 'puzzle', creative activity being its own reward (Sauermann and Stephan, 2013).

Nevertheless, scientists, like most economic agents, may also be interested in pecuniary and non-pecuniary rewards (Levin and Stephan, 1991), the latter including resources for research and reputation gains (e.g., Lam, 2015). Lam (2015) describes some scientists as "strategic commercializers" in that they incorporate commercial practices into their scientific activities. They attempt to influence or manipulate the expectations of their industrial partners in order to shape the relationships. Nevertheless, Cunningham et al. (2014) found that principal investigators were not primarily driven by pecuniary rewards. Acknowledging the diversity of scientists' motivation for engaging with industry, we focus on the possibility to attract funding for research projects, on peer effects and university norms.

Funding. Aggregate statistics from the OECD show that the share of industry-funded research performed by universities has increased considerably over the past two decades (Czarnitzki et al., 2015b). Attracting funding from industry may obviously play a role in motivating scientists to engage with industry. Lee (2000) found that the most significant benefit of commercialization realized by scientists is complementing their own academic research by securing funds for graduate students, gaining access to lab equipment and seeking insights into their own research. Reflecting on their collaborative experience, an overwhelming majority of the researchers interviewed said that in the future they would 
expand or at least maintain their present level of collaboration. This is consistent with the finding that scientists develop specialized funding strategies, focusing on certain funding bodies or on industry (Grimpe, 2012). Bercovitz and Feldman (2008) assumed that faculty members would be responsive to financial incentives and that there would be a direct relationship between licensing royalty distribution rates and the amount of technology transfer across universities.

In that sense, academics may secure funds for personnel like post-docs or graduate students or for lab equipment that they otherwise could not afford. In times of decreasing government funding on the one hand and tougher competition for resources from funding agencies on the other hand, industry funding promises to retain the opportunity to conduct research on self-selected topics, even though industry might impose certain restrictions on the publication of research results (e.g., Czarnitzki et al., 2015b).

Peer effects. Prior research has considerably investigated the role that the peers of the academic and the environment that he or she is working in play in determining his or her engagement with industry. Louis et al. (1989) found that the most important factor behind the involvement of scientists in commercialization was local group norms and culture. Likewise Bercovitz and Feldman (2008) hypothesized that the decision of the scientists to participate in invention disclosures is strongly influenced by (a) training effects, i.e. the norms of the institute where the researchers were trained, (b) leadership effects, i.e. the actions of the chairperson of the department influencing the behavior of the others, and (c) peer effects, i.e. scientists are more likely to be involved in technology transfer if their peers are doing the same. These three factors can be summarized as social imprinting.

After controlling for selection (scientists with a taste for applied research may selfselect in certain environments and into collaboration with colleagues that promote industry involvement), these social imprinting effects have been found to be important (Aschhoff and Grimpe, 2014). Peers may influence other academics, especially those with lower career age, 
to behave in a certain way. Moreover, environments like departments may influence academics' behavior due to communicated tenure and promotion criteria that relate to industry involvement (Goel and Faria, 2010).

Given these motivations for scientists to seek collaboration with industry we expect academics to prefer long-term collaborative, basic research projects where they can pursue novel research questions, secure long term financing, and where results can be open and publishable - without long delays (in accordance with the notion of "Hybrid Commercializers”, Lam, 2015). Academics will typically try to avoid short-term projects as they provide little or no opportunity for publication and force them to shift their work from their research efforts toward short-term goals. In that sense, the opportunity cost of academics can be high. As a result, we expect academics to initiate primarily joint research projects. Moreover, D’Este and Perkmann (2011) show that research-related motives lead academics to engage in contract research. They may also initiate consulting projects in order to generate personal income and informal contacts that may precede joint research, contract research or consulting projects. Scientists are also rather unlikely to initiate in-licensing contracts because most of the proceeds will go to the university. Hence, our second hypothesis reads:

Hypothesis 2: Joint research projects, contract research, consulting, and informal contacts are more likely to be initiated by university scientists compared to in-licensing.

In terms of the management of collaborative activities, we will expect all types of collaborations to be more likely to be managed by firms than by university scientists (Grimpe and Hussinger, 2013). Given the strong pressure on time and cost in industrial R\&D as well as the need to keep tight control over research results once they emerge but also the competence of industrial R\&D to manage projects, it seems likely that we will observe firms taking over the management of projects to a higher degree than university scientists, even if those projects 
were not initiated by the firms (Erez and Shneorson, 1980; Link, Swann, and Bozeman, 2008; Libaers, 2012; Anderson and Slade, 2016; and, broadly, Juster and Stafford, 1991). This may be due to the lack of competence but academics may also be more willing to pass on management tasks in exchange for higher funding or more freedom to set own research priorities. Besides competence, there is the issue of relative incentives - university scientists do not directly benefit by expending efforts to be managers as they generally are not developing university-specific human capital (exceptions being the few academics who aspire to university administrative positions) (Goel and Rich, 2005). On the other hand, firm employees, even those not in management positions, currently have more of an incentive to develop managerial skills and would be eager to undertake management of scientific collaborations. Thus, our third hypothesis reads:

Hypothesis 3: All types of university-industry collaboration are more likely to be managed by firm employees compared to university scientists.

\subsection{Firm size}

Innovation, being an uncertain activity, warrants collaboration to share risks and this might be true of both large and small firms. At the same time, however, firms need to be able to identify promising collaboration partners. A firm’s ability to achieve this has been summarized as absorptive capacity (Cohen and Levinthal, 1990). It refers to the identification of valuable knowledge, its assimilation with existing knowledge and its exploitation for successful innovation. Absorptive capacity is based on a set of organizational routines and processes (Zahra and George, 2002) and often times developed as a by-product of the firm’s own R\&D activities (Cohen and Levinthal, 1989).

Prior research suggests that the development of absorptive capacity implies a continuous commitment to research and innovation (Grimpe and Sofka, 2009). This 
commitment, however, is related to costly investments. Larger firms are more capable of bearing large risks and they are more likely able to make investments into $R \& D$ on a continuous basis. This allows larger firms to better build up absorptive capacity compared to smaller firms and hence to be better positioned for certain types of university-industry collaboration. In fact, prior research has frequently shown that firm size is positively associated with both formal (including joint research, contract research, in-licensing, and consulting) and informal modes of collaboration with universities (Fontana et al., 2003; Grimpe and Hussinger, 2013).

Santaro and Chakrabarti (2002) note differences across small and large firms in hightech university industry collaborations and point out the significant role of technology leaders, i.e. firms with high absorptive capacity, being more likely to successfully establish collaboration. Laperche and Liu (2013) note that small firms relatively record weaker performances in terms of absorptive capacity and implementation of open innovation strategy. They also suggest that the incentives and capabilities for interactions might be different across small and large firms. Both firm experience (e.g., Bruneel et al., 2010) and age (e.g., Cunningham and Link, 2016) are associated with successfully building up such absorptive capacity in order to interact with universities. Nevertheless, since small firms have fewer resources and lower absorptive capacity available, they may have a particular interest in initiating those types of collaboration that require lower resource commitment, management attention (Ocasio, 1997) and that may result in new knowledge which is easy to integrate into the firm’s innovation processes (Vahter, Love, and Roper, 2014).

Firm size is also important in regard to public funding for research (e.g., Aschhoff, 2010). On the one hand, large firms might signify stability and thus provide greater assurance about eventual execution of research projects, making them good candidates for public support. On the other hand, large firms might be viewed as internally capable to fund research 
and this might decrease their chances. In contrast, small firms are more deserving of public support, while their chances of execution might be viewed less favorably a priori.

In sum, these arguments paint a differentiated picture when considering firm size, the types of collaborations and the initiation and management by firm employees or university scientists. For this reason, we will not formulate specific hypotheses as there are too many possible combinations. Rather, we will investigate to what extent the relationships hypothesized before also hold when we distinguish between small and large firms or whether they need qualification.

\section{Methods}

\subsection{Data}

Our research uses data from the German part of the European Community Innovation Survey (CIS), called "Mannheim Innovation Panel (MIP)”. The survey has been conducted annually since 1992 by the Centre for European Economic Research (ZEW) and constitutes the official innovation reporting of the German government. Our data stem from the survey conducted in 2003 which includes rich information on university-industry interaction but which is also the only survey in the German Community Innovation Survey that contains detailed questions on the initiation and management of university-industry collaboration. In line with other literature (e.g., Grimpe and Hussinger, 2013), we limit the sample to manufacturing firms as knowledge and technology transfer through such interaction has a very different nature for service firms. University-industry collaboration in the services sector entails considerable differences compared to manufacturing. Competitive advantage in services sectors is often times not based on new technological knowledge embodied in new products. In fact, most services cannot be easily protected by formal means of protection such as patents. Hence, there would be no need to license technology. Besides, our arguments have stressed the role 
of new technology that universities may be able to supply to firms. Including services sectors would have therefore not fitted our theoretical arguments. Moreover, the sample is limited to firms which actually reported having collaborated with universities and other public research institutes because otherwise the question of who initiated and who eventually managed the collaboration would not arise. Excluding observations with item non-response our final sample includes 833 firms.

\subsection{Measures}

The dependent variables refer to the various modes of collaboration. In the questionnaire, firms are asked to indicate whether they have collaborated with universities or public research institutes in the period from 2000-2002 ("Has your company collaborated with a scientific institution (university and other public research institutes) using one of the following collaboration modes in the period 2000-2002?”). As mentioned above, our research focuses on five modes of collaboration, namely joint research, contract research, technology consulting, in-licensing and acquisition of technologies developed at universities, and informal contacts. Prior literature has characterized the former four modes as formal collaboration since interaction between academia and industry is based upon a contractual relationship (Goel and Göktepe-Hultén, 2013; Goel and Grimpe, 2013; Grimpe and Hussinger, 2013). In our sample, 95 percent of the firms report having formally collaborated with universities while only five percent only collaborated informally.

The explanatory variables include two dummy variables indicating that universityindustry interaction was initiated (or managed) by firm employees or university scientists. Moreover, we control for a number of factors. First, we control for whether the university technology transfer office (TTO) has been involved in the initiation and management of collaboration. The TTO, however, plays arguably only a minor role in this respect since most universities did not have a TTO infrastructure at the time the survey was conducted (2003). 
The "professor's privilege” was only abolished in Germany in 2002, equivalent to the BayhDole Act in the United States, assigning the intellectual property rights on inventions made by university scientists to the university (Czarnitzki et al., 2007, 2009). Moreover, we include the patent stock per employee which can be interpreted as a measure of the firm's accumulated technological capabilities. Data for this variable are taken from the PATSTAT database on patents filed at the European Patent Office. We also control for the firm’s R\&D intensity, measured as the expenditures on R\&D per employee, and whether the firm indicates to have followed a technology leadership strategy in order to capture the firm's strategic intent to innovate. Both variables capture the firm's strategic intent with regard to technology and innovation and they provide a measure for the extent the firm's innovation processes are based on technology. Since university-industry collaboration may be driven by the availability of public funding (and hence such type of collaboration is a pre-requisite for obtaining funding), we include three dummy variables indicating whether the firm received public innovation subsidies on the state, federal or EU level. Further, we control for firm size measured as the number of employees, whether the firm is located in East Germany, a region that is still lagging behind economically, and whether the firm is part of a group of firms. Finally, the regression models include industry dummy variables for medium-tech and hightech manufacturing based on grouped 2-digit European NACE industries, with low-tech manufacturing being the reference category. These account for qualitative differences (e.g., technological or regulatory) across industries.

\subsection{Model}

Due to the cross-sectional nature of our data, the regressions should be interpreted as providing multivariate correlations rather than causal relationships. In that sense, we estimate a series of probit models explaining each of the five modes of collaboration, by regressing those first on the initiation and second on the management variables. Moreover, we estimate 
multivariate probit models in order to account for the fact that certain modes of collaboration may occur together with another mode, i.e. we take the correlation between the unobserved determinants of any two collaboration modes into account. To investigate the differences in firm size, we split the sample into small firms (defined as those having less than 250 employees) and large firms (with 250 employees and more).

The following equation helps provide structure to the discussion and formally sets up our empirical approach (with subscript $i$ denoting a firm in our sample):

University-industry collaboration $_{i j}=f$ (initiator $_{i m}$, research $_{i x}$, funding $_{i y}$, industry , firm $_{i z}$ characteristics $\left.{ }_{i k}\right)$

$$
\begin{aligned}
& i=1, \ldots, 833 \\
& j=\text { initiation, management (joint research, contract } \\
& \text { research, in-licensing, consulting, informal contacts) } \\
& m=\text { firm employees, university scientists } \\
& k=\text { location, strategy, employees } \\
& x=\text { patent stock/employee, R\&D/employee } \\
& y=\text { state, federal, EU } \\
& z=\text { low-tech, medium-tech, high-tech manufacturing }
\end{aligned}
$$

The results, based alternately on collaboration initiation and collaboration management, are next.

\section{Results}

\subsection{Descriptive findings}

Table 1 provides descriptive statistics for all firms as well as for small and large firms.

Differences in mean values of the variables for small and large firms are tested for statistical significance. The table shows that, among those formal modes of collaboration, consulting, 
followed by joint research and contract research are the most prevalent. Consulting has been found to be prevalent also in the U.S. context because it constitutes an important way for scientists to increase their research budgets (e.g., Link et al., 2007). In-licensing from universities is only reported by 15 percent of the firms. An explanation for this rather low rate is the professor's privilege which had been in place in Germany until 2002. This has been argued to have resulted in a low number of patents stemming from German universities which, as a consequence, leads to low licensing income compared to the U.S. where the BayhDole Act had come into force already more than 20 years earlier (Czarnitzki, Glänzel, and Hussinger, 2007, 2009).

There is no statistically significant difference in the mean occurrence of joint research projects between small and large firms. However, contract research, in-licensing, consulting and informal contacts are significantly more likely to occur in large firms.

Insert Table 1 about here

Regarding the main explanatory variables on who initiated and who managed the collaboration, Table 1 shows that most of the collaborative activities are initiated and managed by firm employees. University scientists (and particularly the university TTOs) play a less important role. Considering that most collaboration is through consulting, these frequencies already indicate firm employees to be the primary initiators and managers of such activities. Table 1 further shows that a considerable share of the firms received funding from one of the three sources, which indicates the importance of funding for forming collaborative agreements.

Table 2 shows pairwise correlations and includes both the initiation and the management variables although they enter the regression models separately. There is no indication for collinearity problems in our data; the variance inflation factor (VIF) in both the 
initiation and the management models (including all industry dummies) is 1.25 and the condition number is 12.47 (12.64) which is well below the conventionally applied thresholds (Belsley, Kuh, and Welsh, 1980).

Insert Table 2 about here

\subsection{Regression results}

\subsubsection{Initiation of collaboration}

Table 3 shows the results for the five modes of collaboration under study (see equation (1)). It turns out that an initiation by university scientists is positively related to all modes of collaboration but in-licensing, while only consulting and informal contacts (and to some extent also joint research projects) are more likely to be initiated by firm employees. Hence, hypotheses 1 and 2 receive support, with the only exception that hypothesis 1 also predicted firm employees to initiate in-licensing contracts. These findings substantiate the high importance of university scientists for the initial establishment of most collaborative activity with industry. In that regard, it seems to be more a "technology push" from university to industry rather than a "technology pull” by industry. Scientists may be pressured to attract industry funding or may be interested in using infrastructure at industrial labs that they do not have available or cannot afford themselves. That firm employees are apparently only connected to initiating consulting or informal contacts may indicate some reluctance on their behalf towards committing considerable time and resources to university-industry relationships as it would be necessary in case of joint research, contract research or inlicensing. 


\subsubsection{Management of collaboration}

Next, we investigate the question by whom the different modes of collaboration are managed. Table 4 shows the results. We find similarities but also striking differences compared to the previous model. First of all, university scientists are also the ones managing many of the relationships once they initiated them. There is a significant positive association for all five modes of collaboration. However, we also find that firm employees gain much more importance when it comes to managing the collaboration. Except for in-licensing, which also makes sense since in-licensing constitutes a very limited degree of interaction but rather a transaction, firm employees are equally likely to manage the collaboration. Hence, due to the mixed results, hypothesis 3 has to be rejected. Apparently, once firm employees have overcome their reluctance and committed resources to the collaboration they are also keen on managing the collaborative venture in order to make sure that the outcome meets the firm's objectives. Due to the routines established in industrial R\&D, firm employees are also likely to be better able managing collaborative projects.

\section{Insert Table 4 about here}

The results for the control variables are highly similar for both models. We only find consulting and to a limited extent also contract research to be more likely initiated by the university TTO. ${ }^{2}$ We also find little importance of the firm’s patent stock, except for a

\footnotetext{
${ }^{2}$ A part of the reason for the relative insignificance of the influence of TTOs might be that their role is often not well-defined as they are trying to cater to multiple constituencies, notably university researchers on the one hand and university management on the other (O'Kane et al., 2015).
} 
negative association with contract research, but strong positive relationships between the firm’s R\&D intensity and contract research and in-licensing. This finding is interesting because it provides evidence for the importance of having built up absorptive capacity in order to benefit from university research (Cohen and Levinthal, 1990), for which investments into R\&D typically serve the purpose. It also illustrates that research-intensive firms use contract research and the in-licensing of technology in order to complement their own innovation efforts since both modes normally aim at solving clearly delimited technological problems. Further, we find that firms following a technology leadership strategy engage in joint research and contract research.

With respect to public support for innovation, obtaining state, federal or EU funding increases the likelihood that firms are engaged in joint research or contract research projects with universities. This finding likely reflects the requirement of many public support schemes to collaborate between industry and science. Regarding firm size, we find that larger firms favor contract research and in-licensing. There are virtually no significant associations between the location of a firm and the organizational structure and the choice for a particular collaboration mode. Firms located in East Germany are somewhat less likely to engage in joint research and in-licensing which may reflect lower technological absorptive capacity of firms that are also economically lagging behind.

\subsubsection{Robustness check}

As a robustness check, we estimate multivariate probit models that show the correlation coefficients between the error terms (rho), i.e. the unobserved determinants of the five modes of collaboration. These correlation coefficients provide an indication of which modes may be jointly influenced by unobserved factors and hence are likely to be chosen together by the firm. Prior research has also used rho as an indication of complementarity between certain organizational practices (e.g., Athey and Stern, 1998). When performed on the equations 
including the initiation variables, the multivariate probit results are fully consistent with the single probits. Moreover, regarding the correlation of the error terms, it turns out that all but three are positive and significantly correlated with each other. This refers to the rho between the equations for joint research and informal contacts, for contract research and informal contacts, and for in-licensing and informal contacts. Except for consulting that seems to be somewhat complementary with informal contacts, the other collaboration modes appear not to be determined by the same unobserved factors as informal contacts are, suggesting them to be less complementary.

When the multivariate probit is performed on the equations containing the management variables, the results are again fully consistent with the single probits. With respect to the correlation coefficients, not surprisingly the same picture evolves as in the previous model. All are positive and significant, except for the three rho's between the equations involving informal contacts. ${ }^{3}$

\subsubsection{Effects of firm size}

To obtain further insights into university-industry interaction by small and large firms, we examine the effects of firm size by splitting the sample accordingly. Tables 5 and 6 provide corresponding results for small and large firms across collaboration initiation and managements. We find some interesting similarities and differences across the various dimensions considered - namely, across initiation and management, across small and large firms, and across the type of interaction.

There are remarkable differences between small and large firms for the initiation of university-industry interaction (Table 5). While firm employees in both small and large firms are likely to initiate consulting and informal contacts, it is university scientists that are much more likely to initiate joint research and informal contacts with small firms than with large

\footnotetext{
${ }^{3}$ These results are not reported but are available upon request.
} 
firms. They are also likely to initiate, irrespective of firms size, contract research and consulting. As a result, we find hypothesis 1 to hold particularly for small firms because large firms apparently do initiate joint research projects. By contrast, hypothesis 2 holds particularly in the case of small firms, although it has to be noted that the coefficients in the large firm sample show the expected sign but are insignificant. This indicates that university scientists may find it much easier to approach smaller firms when it comes to setting up more complex joint research projects. It is apparently also easier for university scientists to establish informal contacts with smaller firms, suggesting that these types of firms are easier to approach and negotiate a contract with.

There are also several interesting differences between small and large firms when it comes to the management of university-industry interaction (Table 6). Firm employees in small firms are much more likely to take over management of joint research and contract research projects than employees in large firms. Apparently, smaller firm size does not mean that the firm is particularly restricted in its resources to manage such collaborative projects. Rather, it seems that the management skills and routines required to manage universityindustry interaction do not depend on firm size. Both for small and large firms, firm employees are likely to manage consulting and informal contacts. University scientists are likely to take over management of all types of collaboration with small firms, but only contract research, consulting and, to a limited extend, informal contacts in the case of large firms. This indicates that scientists are confident to manage such relationships in the case of small firms and that small firms do not generally seem to have a tendency to take over management of the projects once they are initiated. In case of collaborating with large firms, however, university scientists are less likely to be involved in the management of joint research and in-licensing projects. As a result, we find hypothesis 3 to be largely rejected.

As a further investigation into the role of firm size, we have re-estimated the models using a sample of firms with less than 50 employees. The results turn out to be fully 
consistent with the sample of firms $\leq 250$ employees regarding the initiation of collaboration. However, when we look at the management of collaboration it turns out that firm employees in firms $\leq 50$ employees are not at all involved in the management of the collaborative projects. This is an interesting, even though expected finding. ${ }^{4}$ Overall, our consideration of firm size provides additional insights into the complex nature of interactions between science and industry.

Insert Table 5 about here

Insert Table 6 about here

\section{Discussion}

Using survey data on a large sample of German firms, this research focuses on the question how university-industry interaction gets established in the first place, and specifically to whom the establishment of joint research projects, contract research, in-licensing, consulting, and informal contacts may be attributed. Once initiated, our research has also looked into who manages these collaborative projects. In the context of the literature, our study adds to studies that examine university-industry collaborations (e.g., D’Este and Perkmann, 2011), by providing insights about differences in initiation versus management of such collaborations. Our research indicated that in the process of university-industry relations the role of university scientists is often narrowed down to the production of new knowledge or solving research

\footnotetext{
${ }^{4}$ The results are available from the authors upon request.
} 
problems while industry is often the consumer of this knowledge. We highlight that university scientists may play a more active role in establishing and managing these relations.

In our first hypothesis, we suggested in-licensing, consulting and informal contacts to be more likely to be initiated by firm employees compared to joint research and contract research. On the contrary, we suggested in hypothesis 2 that joint research projects, contract research, consulting, and informal contacts are more likely to be initiated by university scientists compared to in-licensing. In fact, we find stark differences between the five formal and informal collaboration modes considered: While individual university scientists turn out to be instrumental in establishing all modes of collaboration but in-licensing, firm R\&D employees are important only for initiating consulting projects and informal contacts. Thus, university scientists seem to be mostly behaving "strategically” in initiating collaborations, in the vein of arguments presented in prior literature (Lam, 2015; O'Kane et al., 2015). They are interested in accessing research infrastructure and obtaining funding for research projects which may eventually enable them to publish the outcomes of their research (Grimpe, 2012). Therefore, our results add to the discussion on the role of university scientists as principal investigator establishing and managing collaborative projects (Boehm and Hogan, 2014; Cunningham et al., 2014; Cunningham et al., 2016).

While institutionalizing university-industry collaboration has become one of the top issues for policy-makers in many industrialized countries (Bozeman, 2000), it has been criticized that institutions such as the patent system and intermediaries like technology transfer offices may not necessarily facilitate university-industry relations (Mowery et al., 2001; Siegel, Veugelers, and Wright, 2007). Our findings suggest that, while individual scientists are often instrumental in the initiation of university-industry collaboration, formalization of the process would yield more sustainable relationships. The relationships we observe may heavily rely on the individual professor and on his/her individual networks, capacity, reputation as well as willingness to initiate relations with industry (Boehm and 
Hogan, 2014; Audretsch and Göktepe-Hultén, 2015). Individual scientists may play an important role in establishing an entrepreneurial culture at universities and public research organizations and adding formal institutions and organizations may enable other scientists to become more active in initiating collaborative relations with industry (Göktepe-Hultén, 2008).

On the issue of initiation versus management, which we investigated in hypothesis 3 , firm employees are relatively less likely to initiate collaborations than their university counterparts but they seem to generally take over management once the collaboration has been established. This can be attributed to differences in time horizons between university scientists (long-term) and firm employees (short-term) (Link et al., 2008; Libaers, 2012; Anderson and Slade, 2016; and, broadly, Juster and Stafford, 1991) as well as to differences in personality types (Erez and Shneorson, 1980). University scientists are interested in actually carrying out the research but they would rather avoid administration and management tasks of those projects (Grimpe, 2012). In line with the above discussion, formal structures like TTOs may also provide administrative and managerial help for scientists who are not interested or not capable of handling knowledge transfer (Göktepe-Hultén and Mahagaonkar, 2010). TTOs should ideally provide a platform for managing these relations.

The size of firms, as noted above, may be an important determinant of firms' willingness and ability to enter into collaborative research agreements with universities. Our sample split between small and large firms provides important nuances to the observed relationships: By and large, university scientists are more effective in initiating collaboration with smaller firms than with larger firms, while it is often times the firm employees in smaller firms compared to larger firms that take over the management of the collaboration projects. This is consistent with the notion that small firms are more nimble and might have lower transactions costs.

Our research holds several insights. The first of these is the time horizon of the collaboration. Short-term collaborations are useful, common and relatively easy to facilitate if 
they are targeted and aligned to universities' and academics’ ways of working. However, they require creative structuring, as the clock speed of academic research and business practice can be wildly divergent. Conversely, many academics think long-term, and this can be an advantage for a business as it may overcome managers' tendency to look to the next quarter (Link et al., 2008; Libaers, 2012; Anderson and Slade, 2016; and, broadly, Juster and Stafford, 1991). “Going long” with academics in the search for new ideas can unlock a range of possibilities and even help to create a new innovation ecosystem that will sustain the business for longer periods of time into the future (O'Kane et al., 2015). However, such longterm collaborations require more patient investment and managerial attention to the design and governance of the collaboration or they can go easily away. One consideration might be that in the age of startups in the new digital economy, where scale increases are much easier than traditional manufacturing and time horizons are short, perhaps academics need to reconsider their approaches to be more lucrative collaborators.

\section{Conclusion}

Our research holds several implications for university scientists, firm employees and intermediaries supporting university-industry collaboration. First, our findings indicate that university scientists find it easier to initiate contacts with smaller firms which may be particularly suitable partners for joint research projects that not only lead to outcomes that the firms can commercialize but also to scientific results that can be published. These projects seem often times accompanied by informal contacts that facilitate mutual trust and knowledge exchange. Hence, interaction with smaller firms is much more aligned with scientists’ publication objectives. Second, firm employees primarily turn out be instrumental in instigating consulting relationships with universities, irrespective of firm size. Although they typically take over the management of other types of projects, it may be beneficial to actually 
instigate those other types of projects as well. This would allow firms to much more deliberately search for knowledge and technology they require in their innovation process and tailor knowledge acquisition processes more tightly to their needs. Small firms seem to have an advantage in setting up joint research projects because such projects meet with university scientists’ preferences. This leads to implications for technology transfer offices (TTOs) as the intermediaries of university-industry collaboration.

The traditional notion behind the formation of TTOs is to facilitate (initiate and manage) university-industry relations. Our research has shown that for most knowledge transfer channels university scientists play an important role as an instigator while firms seem to take on more managerial roles during the process of knowledge transfer. As such there is little need for the formation of TTOs. However a technology transfer system that solely relies on individual university scientists' motivation and ability to initiate relations with industry or a system where firms are managing the relations afterwards may not be sustainable in the long term. Through formal support and procedures TTOs may enable passive scientists to take part in technology transfer, and may act as a platform for managing the process together with scientists and firms. Most importantly, TTOs need to be aware of the differences in motivations between university scientists and firm employees. But they also need to understand the differences between small and large firms in the likelihood to instigate certain types of collaboration. This enables TTOs to more effectively pave the way for collaborative agreements.

Finally, this research can be seen as making initial inroads into the intricacies of interactions between academia and industry. Our study has highlighted that, in this evolutionary perspective, firm size will have an important role to play in order to account for the differences in management skills, operational routines and financial and resource endowments between small and large firms. 
As more information becomes available, other aspects of such interactions may be examined. This hints at the limitations of our study that can only observe cross-sectional multivariate correlations. It would be very much desirable for future research to collect longitudinal data on the evolution of university-industry interaction, observing not only the initiation and the conditions under which certain types of collaboration are initiated by a certain partner, but also the eventual outcome of such collaboration, for example in terms of patents, university-industry co-publications or other improvements in the innovation processes of firms.

In future research, data on the life of firms would enable one to examine whether older firms were more likely to collaborate with university scientists because those firms have built up the appropriate collaborative routines, or whether younger firms are more likely to do so because these firms are typically characterized by less bureaucracy and formalization. It would also be instructive to see how findings based on German data hold for other nations. 


\section{References}

Adams JD. 1990. Fundamental Stocks of Knowledge and Productivity Growth. Journal of Political Economy 98: 673-702.

Anderson DM, Slade CP. 2016. Managing Institutional Research Advancement: Implications from a University Faculty Time Allocation Study. Research in Higher Education 57(1): 99-121.

Antonelli C, Link AN (Eds.). 2015. Routledge Handbook of the Economics of Knowledge. Routledge: Oxon.

Aschhoff B. 2010. Who Gets the Money? The Dynamics of R\&D Project Subsidies in Germany. Journal of Economics and Statistics 230(5): 522-546.

Aschhoff B, Grimpe C. 2014. Contemporaneous Peer Effects, Career Age and the Industry Involvement of Academics in Biotechnology. Resarch Policy 43: 367-381.

Athey S, Stern S. 1998. An Empirical Framework for Testing Theories About Complementarity in Organizational Design, NBER Working Paper: Boston.

Audretsch DB, Göktepe-Hultén D. 2015. University Patenting in Europe. In AN Link, DS Siegel, M Wright (Eds.), The Chicago Handbook of University Technology Transfer and Academic Entrepreneurship. University of Chicago Press: Chicago, IL: 188-217.

Belsley DA, Kuh E, Welsh RE. 1980. Regression Diagnostics: Identifying Influential Data and Sources of Collinearity: New York.

Bercovitz J, Feldman M. 2008. Academic Entrepreneurs: Organizational Change at the Individual Level. Organization Science 19(1): 69-89.

Boehm DN, Hogan T. 2014. 'A Jack of All Trades': The Role of Pis in the Establishment and Management of Collaborative Networks in Scientific Knowledge Commercialisation. Journal of Technology Transfer 39(1): 134-149.

Bozeman B. 2000. Technology Transfer and Public Policy: A Review of Research and Theory. Research Policy 29: 627-655.

Bozeman B, Fay D, Slade CP. 2013. Research Collaboration in Universities and Academic Entrepreneurship: The-State-of-the-Art. Journal of Technology Transfer 38: 1-67.

Bruneel J, D’Este P, Salter A. 2010. Investigating the Factors That Diminish the Barriers to University-Industry Collaboration. Research Policy 39: 858-868.

Cassiman B, Veugelers R, Zuniga MP. 2008. In Search of Performance Effects of (in)Direct Industry Science Links. Industrial and Corporate Change 17(4): 611-646.

Cockburn IM, Henderson RM. 1998. Absorptive Capacity, Coauthoring Behavior, and the Organization of Research in Drug Discovery. Journal of Industrial Economics 46(2): 157-182.

Cohen WM, Levinthal DA. 1989. Innovation and Learning: The Two Faces of R\&D. The Economic Journal 99(397): 569-596.

Cohen WM, Levinthal DA. 1990. Absorptive Capacity: A New Perspective on Learning and Innovation. Administrative Science Quarterly 35(1): 128-152.

Cunningham JA, Link AN. 2016. Exploring the Effectiveness of Research and Innovation Policies among European Union Countries. International Entrepreneurship and Management Journal forthcoming

Cunningham JA, Mangematin V, O'Kane C, O'Reilly P. 2016. At the Frontiers of Scientific Advancement: The Factors That Influence Scientists to Become or Choose to Become Publicly Funded Principal Investigators. Journal of Technology Transfer 41(4): 778797.

Cunningham JA, O'Reilly P, O'Kane C, Mangematin V. 2014. The Inhibiting Factors That Principal Investigators Experience in Leading Publicly Funded Research. Journal of Technology Transfer 39(1): 93-110. 
Czarnitzki D, Glänzel W, Hussinger K. 2007. Patent and Publication Activities of German Professors: An Empirical Assessment of Their Co-Activity. Research Evaluation 16(4): 311-319.

Czarnitzki D, Glänzel W, Hussinger K. 2009. Heterogeneity of Patenting Activity and Its Implications for Scientific Research. Research Policy 38: 26-34.

Czarnitzki D, Grimpe C, Pellens M. 2015a. Access to Research Inputs: Open Science Versus the Entrepreneurial University. Journal of Technology Transfer 40(6): 1050-1063.

Czarnitzki D, Grimpe C, Toole AA. 2015b. Delay and Secrecy: Does Industry Sponsorship Jeopardize Disclosure of Academic Research? Industrial and Corporate Change 24: 251-279.

D'Este P, Patel P. 2007. University-Industry Linkages in the Uk: What Are the Factors Underlying the Variety of Interactions with Industry? Research Policy 36(9): 12951313.

D’Este P, Perkmann M. 2011. Why Do Academics Engage with Industry? The Entrepreneurial University and Individual Motivations. Journal of Technology Transfer 36: 316-339.

Erez M, Shneorson Z. 1980. Personality Types and Motivational Characteristics of Academics Versus Professionals in Industry in the Same Occupational Discipline. Journal of Vocational Behavior 17(1): 95-105.

Faria JR. 2005. The Games Academics Play: Editors Versus Authors. Bulletin of Economic Research 57: 1-12.

Fontana R, Geuna A, Matt M. 2003. Firm Size and Openness: The Driving Forces of University-Industry Collaboration, SPRU Electronic Working Paper Series: Brighton.

Franzoni C. 2009. Do Scientists Get Fundamental Research Ideas by Solving Practical Problems? Industrial and Corporate Change 18(4): 671-699.

Goel RK, Faria JR. 2010. Returns to Networking in Academia. Netnomics 11: 103-117.

Goel RK, Göktepe-Hultén D. 2013. Industrial Interactions and Academic Patenting: Evidence from German Scientists. Economics of Innovation and New Technologies 22: 551-565.

Goel RK, Grimpe C. 2013. Active Versus Passive Academic Networking: Evidence from Micro-Level Data. Journal of Technology Transfer 38: 116-134.

Goel RK, Rich DP. 2005. Organization of Markets for Science and Technology. Journal of Institutional and Theoretical Economics 161: 1-17.

Göktepe-Hultén D. 2008. Academic Inventors and Research Groups: Entrepreneurial Cultures at Universities. Science and Public Policy 35: 657-667.

Göktepe-Hultén D, Mahagaonkar P. 2010. Inventing and Patenting Activities of Scientists: In the Expectation of Money or Reputation? Journal of Technology Transfer 35: 401-423.

Grimpe C. 2012. Extramural Research Grants and Scientists’ Funding Strategies: Beggars Can’t Be Choosers? Research Policy 41: 1448-1460.

Grimpe C, Fier H. 2010. Informal University Technology Transfer: A Comparison between the United States and Germany. Journal of Technology Transfer 35: 637-650.

Grimpe C, Hussinger K. 2013. Formal and Informal Technology Transfer from Academia to Industry: Complementarity Effects and Innovation Performance. Industry and Innovation 20(8): 683-700.

Grimpe C, Sofka W. 2009. Search Patterns and Absorptive Capacity: Low- and HighTechnology Sectors in European Countries. Research Policy 38: 495-506.

Jaffe A. 1989. Real Effects of Academic Research. American Economic Review 97(5): 957970.

Jensen R, Thursby J, Thursby M. 2010. University-Industry Spillovers, Government Funding, and Industrial Consulting, NBER Working Paper: Cambridge, MA.

Jensen RA, Thursby MC. 2001. Proofs and Prototypes for Sale: The Licensing of University Inventions. American Economic Review 91: 240-259. 
Juster FT, Stafford FP. 1991. The Allocation of Time: Empirical Findings, Behavioral Models, and Problems of Measurement. Journal of Economic Literature 29(2): 471522.

Köhler C, Sofka W, Grimpe C. 2012. Selective Search, Sectoral Patterns, and the Impact on Product Innovation Performance. Research Policy 41(8): 1344-1356.

Lam A. 2015. Academic Scientists and Knowledge Commercialization: Self-Determination and Diverse Motivations. In IM Welpe, J Wollersheim, S Ringelhan, M Osterloh (Eds.), Incentives and Performance: Governance of Research Organizations. Springer: Berlin: 173-187.

Laperche B, Liu Z. 2013. Smes and Knowledge-Capital Formation in Innovation Networks: A Review of Literature. Journal of Innovation and Entrepreneurship 2(1): 1-16.

Laursen K, Salter A. 2004. Searching High and Low: What Type of Firms Use Universities as a Source of Innovation. Resarch Policy 33(8): 1201-1215.

Lee YS. 2000. The Sustainability of University-Industry Research Collaboration: An Empirical Assessment. Journal of Technology Transfer 25: 111-133.

Levin SG, Stephan PE. 1991. Research Productivity over the Life Cycle: Evidence for Academic Scientists. American Economic Review 81(1): 114-132.

Libaers DP. 2012. Time Allocation Decisions of Academic Scientists and Their Impact on Technology Commercialization. IEEE Transactions on Engineering Management 59(4): 705-716.

Link AN, Siegel DS, Bozeman B. 2007. An Empirical Analysis of the Propensity of Academics to Engage in Informal University Technology Transfer. Industrial \& Corporate Change 16(4): 641-655.

Link AN, Swann CA, Bozeman B. 2008. A Time Allocation Study of University Faculty. Economics of Education Review 27(4): 363-374.

Louis KS, Blumenthal D, Gluck ME, Stoto MA. 1989. Entrepreneurs in Academe: An Exploration of Behaviors among Life Scientists. Administrative Science Quaterly 34: 110-131.

Merton RK. 1973. The Normative Structure of Science. In RK Merton (Ed.), The Sociology of Science: Theoretical and Empirical Investigations. The University of Chicago Press: Chicago, IL.

Mowery DC, Nelson RR, Sampat BN, Ziedonis AA. 2001. The Growth of Patenting and Licensing by U.S. Universities: An Assessment of the Effects of the Bayh-Dole Act of 1980. Research Policy 30(1): 99-119.

Muscio A, Vallanti G. 2014. Perceived Obstacles to University-Industry Collaboration: Results from a Qualitative Survey of Italian Academic Departments. Industry and innovation 21(5): 410-429.

O'Kane C, Cunningham JA, Mangematin V, O'Reilly P. 2015. Underpinning Strategic Behaviours and Posture of Principal Investigators in Transition/Uncertain Environments. Long Range Planning 48: 200-214.

Ocasio W. 1997. Towards an Attention-Based View of the Firm. Strategic Management Journal 18: 187-206.

Perkmann M, Salter A. 2012. How to Create Productive Partnerships with Universities. MIT Sloan Management Review 53(4): 79-88.

Perkmann M, Walsh K. 2007. University-Industry Relationships and Open Innovation: Towards a Research Agenda. International Journal of Management Reviews 9(4): 259280.

Reinganum JF. 1983. Uncertain Innovation and the Persistence of Monopoly. American Economic Review 73: 741-748.

Rothaermel FT, Agung SD, Jiang L. 2007. University Entrepreneurship: A Taxonomy of the Literature. Industrial \& Corporate Change 16(4): 691-791. 
Santaro MD, Chakrabati AK. 2002. Firm Size and Technology Centrality in UniversityIndustry Interactions. Research Policy 31: 1163-1180.

Sauermann H, Stephan PE. 2013. Conflicting Logics? A Multidimensional View of Industrial and Academic Science. Organization Science 24(3): 889-909.

Siegel D, Veugelers R, Wright M. 2007. Technology Transfer Offices and Commercialization of University Intellectual Property: Performance and Policy Implications. Oxford Review of Economic Policy 23(4): 640-640.

Steinmo M. 2015. Collaboration for Innovation: A Case Study on How Social Capital Mitigates Collaborative Challenges in University-Industry Research Alliances. Industry and innovation 22(7): 597-624.

Teece DJ. 1986. Profiting from Technological Innovation. Implications for Integration, Collaboration, Licensing and Public Policy. Research Policy 15(6): 285-305.

Thursby JG, Kemp S. 2002. Growth and Productive Efficiency of University Intellectual Property Licensing. Research Policy 31: 109-124.

Vahter P, Love JH, Roper S. 2014. Openness and Innovation Performance: Are Small Firms Different? Industry and innovation 21(7-8): 553-573.

Zahra SA, George G. 2002. Absorptive Capacity: A Review, Reconceptualization, and Extension. Academy of Management Review 27(2): 185-203. 


\section{Tables}

Table 1: Descriptive statistics

\begin{tabular}{llllllll}
\hline & $\begin{array}{l}\text { All firms } \\
(\mathbf{n = 8 3 3})\end{array}$ & $\begin{array}{l}\text { Small firms } \\
(\mathbf{n = 5 2 1 )}\end{array}$ & $\begin{array}{l}\text { Large firms } \\
\text { (n=312) }\end{array}$ & T-test \\
Variable & Mean & SD & Mean & SD & Mean & SD & \\
\hline Joint research (d) & 0.41 & 0.49 & 0.39 & 0.49 & 0.44 & 0.50 & \\
Contract research (d) & 0.37 & 0.48 & 0.29 & 0.45 & 0.50 & 0.50 & $* * *$ \\
In-licensing (d) & 0.15 & 0.36 & 0.13 & 0.34 & 0.19 & 0.39 & $* *$ \\
Consulting (d) & 0.58 & 0.49 & 0.54 & 0.50 & 0.65 & 0.48 & $* * *$ \\
Informal contacts (d) & 0.87 & 0.34 & 0.85 & 0.35 & 0.90 & 0.30 & $*$ \\
Initiated by firm employees (d) & 0.78 & 0.42 & 0.74 & 0.44 & 0.84 & 0.36 & $* * *$ \\
Initiated by university scientists (d) & 0.28 & 0.45 & 0.25 & 0.43 & 0.32 & 0.47 & $* *$ \\
Initiated by university TTO (d) & 0.12 & 0.32 & 0.09 & 0.29 & 0.16 & 0.37 & $* * *$ \\
Managed by firm employees (d) & 0.80 & 0.40 & 0.76 & 0.43 & 0.87 & 0.34 & $* * *$ \\
Managed by university scientists (d) & 0.32 & 0.47 & 0.27 & 0.45 & 0.41 & 0.49 & $* * *$ \\
Managed by university TTO (d) & 0.12 & 0.33 & 0.11 & 0.31 & 0.14 & 0.35 & \\
Patent stock per employee & 0.01 & 0.10 & 0.02 & 0.12 & 0.01 & 0.03 & \\
R\&D per employee & 0.01 & 0.03 & 0.01 & 0.04 & 0.01 & 0.02 & \\
Strategy: technology leadership (d) & 0.47 & 0.50 & 0.40 & 0.49 & 0.57 & 0.50 & $* * *$ \\
State funding (d) & 0.25 & 0.43 & 0.26 & 0.44 & 0.23 & 0.42 & \\
Federal funding (d) & 0.36 & 0.48 & 0.36 & 0.48 & 0.35 & 0.48 & \\
EU funding (d) & 0.14 & 0.35 & 0.10 & 0.31 & 0.21 & 0.41 & $* * *$ \\
No of employees (log) & 5.01 & 1.92 & 3.86 & 1.15 & 6.93 & 1.34 & $* * *$ \\
Location East Germany (d) & 0.33 & 0.47 & 0.43 & 0.50 & 0.16 & 0.37 & $* * *$ \\
Part of group (d) & 0.49 & 0.50 & 0.34 & 0.48 & 0.74 & 0.44 & $* * *$ \\
Low-tech manufacturing (d) & 0.48 & 0.50 & 0.47 & 0.50 & 0.49 & 0.50 & \\
Medium-tech manufacturing (d) & 0.34 & 0.47 & 0.31 & 0.46 & 0.39 & 0.49 & $* *$ \\
High-tech manufacturing (d) & 0.18 & 0.39 & 0.22 & 0.42 & 0.12 & 0.32 & $* * *$ \\
\hline F & & & & & &
\end{tabular}

${ }^{*} \mathrm{p}<0.10,{ }^{* *} \mathrm{p}<0.05$, *** $\mathrm{p}<0.01$; (d) dummy variable 


\section{Table 2: Pairwise correlations}

\begin{tabular}{|c|c|c|c|c|c|c|c|c|c|c|c|c|c|c|c|c|}
\hline & 1 & 2 & 3 & 4 & 5 & 6 & 7 & 8 & 9 & 10 & 11 & 12 & 13 & 14 & 15 & 16 \\
\hline 1. Initiated by firm employees (d) & 1.00 & & & & & & & & & & & & & & & \\
\hline 2. Initiated by university scientists (d) & 0.19 & 1.00 & & & & & & & & & & & & & & \\
\hline 3. Initiated by university TTO (d) & 0.06 & 0.26 & 1.00 & & & & & & & & & & & & & \\
\hline 4. Managed by firm employees (d) & 0.31 & 0.16 & 0.05 & 1.00 & & & & & & & & & & & & \\
\hline 5. Managed by university scientists (d) & 0.14 & 0.37 & 0.13 & 0.22 & 1.00 & & & & & & & & & & & \\
\hline 6. Managed by university TTO (d) & -0.01 & 0.08 & 0.17 & 0.01 & 0.22 & 1.00 & & & & & & & & & & \\
\hline 7. Patent stock per employee & 0.04 & -0.01 & 0.00 & -0.02 & 0.04 & -0.01 & 1.00 & & & & & & & & & \\
\hline 8. R\&D per employee & 0.04 & 0.10 & 0.06 & 0.10 & 0.16 & 0.03 & 0.12 & 1.00 & & & & & & & & \\
\hline 9. Strategy: technology leadership (d) & 0.15 & 0.15 & 0.06 & 0.13 & 0.17 & 0.03 & 0.11 & 0.19 & 1.00 & & & & & & & \\
\hline 10. State funding $(\mathrm{d})$ & 0.10 & 0.17 & 0.08 & 0.11 & 0.15 & 0.08 & 0.05 & 0.13 & 0.11 & 1.00 & & & & & & \\
\hline 11. Federal funding (d) & 0.12 & 0.24 & 0.14 & 0.17 & 0.26 & 0.06 & 0.07 & 0.19 & 0.22 & 0.38 & 1.00 & & & & & \\
\hline 12. EU funding (d) & 0.10 & 0.21 & 0.12 & 0.13 & 0.17 & 0.01 & -0.01 & 0.15 & 0.19 & 0.27 & 0.37 & 1.00 & & & & \\
\hline 13. No of employees 02 (log) & 0.13 & 0.12 & 0.10 & 0.14 & 0.13 & 0.02 & -0.05 & -0.05 & 0.18 & 0.03 & 0.02 & 0.25 & 1.00 & & & \\
\hline 14. Location East Germany (d) & 0.03 & 0.00 & -0.02 & -0.02 & 0.01 & -0.06 & -0.05 & -0.02 & -0.19 & 0.20 & 0.12 & -0.01 & -0.29 & 1.00 & & \\
\hline 15. Part of group (d) & 0.13 & 0.08 & 0.06 & 0.08 & 0.07 & 0.00 & 0.01 & 0.05 & 0.16 & 0.02 & -0.03 & 0.13 & 0.47 & -0.17 & 1.00 & \\
\hline 16. Medium-tech manufacturing (d) & 0.10 & 0.04 & 0.03 & 0.10 & 0.04 & 0.02 & 0.05 & 0.06 & 0.15 & 0.04 & 0.08 & 0.07 & 0.12 & -0.06 & 0.11 & 1.00 \\
\hline 17. High-tech manufacturing (d) & 0.08 & 0.09 & 0.03 & 0.01 & 0.09 & 0.04 & 0.08 & 0.25 & 0.13 & 0.14 & 0.18 & 0.03 & -0.19 & 0.07 & -0.07 & -0.34 \\
\hline
\end{tabular}


Table 3: Probit regression results for the initiation of collaboration

\begin{tabular}{|c|c|c|c|c|c|}
\hline & $\begin{array}{l}\text { Joint } \\
\text { research }\end{array}$ & $\begin{array}{l}\text { Contract } \\
\text { research }\end{array}$ & In-licensing & Consulting & $\begin{array}{l}\text { Informal } \\
\text { contacts }\end{array}$ \\
\hline Initiated by firm employees (d) & $\begin{array}{l}0.225^{*} \\
(0.126)\end{array}$ & $\begin{array}{l}0.059 \\
(0.124)\end{array}$ & $\begin{array}{l}-0.049 \\
(0.144)\end{array}$ & $\begin{array}{l}0.445^{* * *} \\
(0.114)\end{array}$ & $\begin{array}{l}0.721^{* * *} \\
(0.131)\end{array}$ \\
\hline Initiated by university scientists (d) & $\begin{array}{l}0.434 * * * \\
(0.116)\end{array}$ & $\begin{array}{l}0.427 * * * \\
(0.111)\end{array}$ & $\begin{array}{l}0.169 \\
(0.125)\end{array}$ & $\begin{array}{l}0.342^{* * *} \\
(0.112)\end{array}$ & $\begin{array}{l}0.515^{* * *} \\
(0.159)\end{array}$ \\
\hline Initiated by university TTO (d) & $\begin{array}{l}0.243 \\
(0.157)\end{array}$ & $\begin{array}{l}0.255^{*} \\
(0.147)\end{array}$ & $\begin{array}{l}0.242 \\
(0.157)\end{array}$ & $\begin{array}{l}0.547 * * * \\
(0.156)\end{array}$ & $\begin{array}{l}0.165 \\
(0.227)\end{array}$ \\
\hline Patent stock per employee & $\begin{array}{l}-0.027 \\
(0.336)\end{array}$ & $\begin{array}{l}-0.656^{*} \\
(0.351)\end{array}$ & $\begin{array}{l}-1.765 \\
(1.669)\end{array}$ & $\begin{array}{l}-0.149 \\
(0.446)\end{array}$ & $\begin{array}{l}2.945 \\
(2.802)\end{array}$ \\
\hline R\&D per employee & $\begin{array}{l}0.934 \\
(1.525)\end{array}$ & $\begin{array}{l}4.222 * * \\
(1.696)\end{array}$ & $\begin{array}{l}5.076 * * * \\
(1.694)\end{array}$ & $\begin{array}{l}0.396 \\
(1.471)\end{array}$ & $\begin{array}{l}2.374 \\
(3.780)\end{array}$ \\
\hline Strategy: technology leadership (d) & $\begin{array}{l}0.175^{*} \\
(0.105)\end{array}$ & $\begin{array}{l}0.171^{*} \\
(0.102)\end{array}$ & $\begin{array}{l}-0.024 \\
(0.118)\end{array}$ & $\begin{array}{l}0.12 \\
(0.100)\end{array}$ & $\begin{array}{l}0.172 \\
(0.134)\end{array}$ \\
\hline State funding (d) & $\begin{array}{l}0.361^{* * *} \\
(0.123)\end{array}$ & $\begin{array}{l}0.331^{* * *} \\
(0.119)\end{array}$ & $\begin{array}{l}0.161 \\
(0.134)\end{array}$ & $\begin{array}{l}0.173 \\
(0.118)\end{array}$ & $\begin{array}{l}0.258 \\
(0.175)\end{array}$ \\
\hline Federal funding (d) & $\begin{array}{l}0.970 * * * \\
(0.113)\end{array}$ & $\begin{array}{l}0.279 * * \\
(0.112)\end{array}$ & $\begin{array}{l}0.135 \\
(0.126)\end{array}$ & $\begin{array}{l}0.174 \\
(0.113)\end{array}$ & $\begin{array}{l}0.177 \\
(0.161)\end{array}$ \\
\hline EU funding (d) & $\begin{array}{l}0.319 * * \\
(0.153)\end{array}$ & $\begin{array}{l}0.016 \\
(0.149)\end{array}$ & $\begin{array}{l}-0.073 \\
(0.167)\end{array}$ & $\begin{array}{l}0.095 \\
(0.150)\end{array}$ & $\begin{array}{l}0.074 \\
(0.238)\end{array}$ \\
\hline No of employees (log) & $\begin{array}{l}-0.017 \\
(0.032)\end{array}$ & $\begin{array}{l}0.131^{* * *} \\
(0.033)\end{array}$ & $\begin{array}{l}0.075^{* *} \\
(0.035)\end{array}$ & $\begin{array}{l}0.047 \\
(0.029)\end{array}$ & $\begin{array}{l}0.076^{*} \\
(0.043)\end{array}$ \\
\hline Location East Germany (d) & $\begin{array}{l}-0.202 * \\
(0.115)\end{array}$ & $\begin{array}{l}-0.052 \\
(0.110)\end{array}$ & $\begin{array}{l}-0.269 * * \\
(0.134)\end{array}$ & $\begin{array}{l}0.032 \\
(0.105)\end{array}$ & $\begin{array}{l}0.059 \\
(0.135)\end{array}$ \\
\hline Part of group (d) & $\begin{array}{l}-0.008 \\
(0.111)\end{array}$ & $\begin{array}{l}0.039 \\
(0.106)\end{array}$ & $\begin{array}{l}-0.021 \\
(0.124)\end{array}$ & $\begin{array}{l}-0.052 \\
(0.104)\end{array}$ & $\begin{array}{l}-0.209 \\
(0.144)\end{array}$ \\
\hline Medium-tech manufacturing (d) & $\begin{array}{l}0.022 \\
(0.113)\end{array}$ & $\begin{array}{l}0.168 \\
(0.109)\end{array}$ & $\begin{array}{l}0.142 \\
(0.131)\end{array}$ & $\begin{array}{l}0.003 \\
(0.106)\end{array}$ & $\begin{array}{l}0.095 \\
(0.141)\end{array}$ \\
\hline High-tech manufacturing (d) & $\begin{array}{l}-0.013 \\
(0.147)\end{array}$ & $\begin{array}{l}0.161 \\
(0.141)\end{array}$ & $\begin{array}{l}0.482^{* * *} \\
(0.158)\end{array}$ & $\begin{array}{l}-0.15 \\
(0.137)\end{array}$ & $\begin{array}{l}0.071 \\
(0.196)\end{array}$ \\
\hline Constant & $\begin{array}{l}-1.021^{* * *} \\
(0.189)\end{array}$ & $\begin{array}{l}-1.627^{* * *} \\
(0.196) \\
\end{array}$ & $\begin{array}{l}-1.653^{* * *} \\
(0.222) \\
\end{array}$ & $\begin{array}{l}-0.657 * * * \\
(0.170)\end{array}$ & $\begin{array}{l}-0.023 \\
(0.214)\end{array}$ \\
\hline Pseudo R2 & 0.21 & 0.13 & 0.08 & 0.08 & 0.14 \\
\hline $\mathrm{N}$ & 833 & 833 & 833 & 833 & 833 \\
\hline LR/Wald chi2 & 197.364 & 118.876 & 48.921 & 86.472 & 97.41 \\
\hline P-value & 0.00 & 0.00 & 0.00 & 0.00 & 0.00 \\
\hline Log likelihood & -442.189 & -476.469 & -329.599 & -522.773 & -274.932 \\
\hline
\end{tabular}

* $\mathrm{p}<0.10,{ }^{* *} \mathrm{p}<0.05$, *** $\mathrm{p}<0.01$; (d) dummy variable 
Table 4: Probit regression results for the management of collaboration

\begin{tabular}{|c|c|c|c|c|c|}
\hline & $\begin{array}{l}\text { Joint } \\
\text { research }\end{array}$ & $\begin{array}{l}\text { Contract } \\
\text { research }\end{array}$ & In-licensing & Consulting & $\begin{array}{l}\text { Informal } \\
\text { contacts }\end{array}$ \\
\hline \multirow[t]{2}{*}{ Managed by firm employees (d) } & $0.300 * *$ & $0.257 * *$ & -0.051 & $0.437 * * *$ & $0.410^{* * *}$ \\
\hline & $(0.134)$ & $(0.130)$ & $(0.152)$ & $(0.117)$ & $(0.132)$ \\
\hline \multirow[t]{2}{*}{ Managed by university scientists (d) } & $0.358 * * *$ & $0.367 * * *$ & $0.333^{* * *}$ & $0.498 * * *$ & $0.515^{* * *}$ \\
\hline & $(0.108)$ & $(0.107)$ & $(0.121)$ & $(0.107)$ & $(0.155)$ \\
\hline \multirow[t]{2}{*}{ Managed by university TTO (d) } & $0.255^{*}$ & 0.044 & -0.064 & $0.350 * *$ & 0.11 \\
\hline & $(0.154)$ & $(0.146)$ & $(0.175)$ & $(0.150)$ & $(0.202)$ \\
\hline \multirow[t]{2}{*}{ Patent stock per employee } & -0.011 & $-0.641^{*}$ & -1.438 & -0.102 & 3.124 \\
\hline & $(0.335)$ & $(0.347)$ & $(1.367)$ & $(0.451)$ & $(2.736)$ \\
\hline \multirow[t]{2}{*}{ R\&D per employee } & 0.282 & $3.829 * *$ & $4.838 * * *$ & -0.711 & 1.935 \\
\hline & $(1.565)$ & $(1.768)$ & $(1.728)$ & $(1.557)$ & $(4.030)$ \\
\hline \multirow[t]{2}{*}{ Strategy: technology leadership (d) } & 0.169 & 0.161 & -0.044 & 0.12 & 0.189 \\
\hline & $(0.105)$ & $(0.102)$ & $(0.116)$ & $(0.101)$ & $(0.133)$ \\
\hline \multirow[t]{2}{*}{ State funding (d) } & $0.353 * * *$ & $0.334 * * *$ & 0.177 & 0.157 & $0.282 *$ \\
\hline & $(0.122)$ & $(0.119)$ & $(0.135)$ & $(0.118)$ & $(0.171)$ \\
\hline \multirow[t]{2}{*}{ Federal funding (d) } & $0.958 * * *$ & $0.269 * *$ & 0.114 & 0.135 & 0.113 \\
\hline & $(0.113)$ & $(0.112)$ & $(0.126)$ & $(0.114)$ & $(0.165)$ \\
\hline \multirow[t]{2}{*}{ EU funding (d) } & $0.371^{* *}$ & 0.053 & -0.056 & 0.147 & 0.125 \\
\hline & $(0.154)$ & $(0.148)$ & $(0.169)$ & $(0.152)$ & $(0.241)$ \\
\hline \multirow[t]{2}{*}{ No of employees (log) } & -0.02 & $0.126^{* * *}$ & $0.073 * *$ & 0.044 & $0.089 * *$ \\
\hline & $(0.032)$ & $(0.032)$ & $(0.035)$ & $(0.029)$ & $(0.041)$ \\
\hline \multirow[t]{2}{*}{ Location East Germany (d) } & -0.179 & -0.053 & $-0.285 * *$ & 0.077 & 0.122 \\
\hline & $(0.116)$ & $(0.111)$ & $(0.135)$ & $(0.104)$ & $(0.135)$ \\
\hline \multirow[t]{2}{*}{ Part of group (d) } & 0.021 & 0.055 & -0.024 & -0.001 & -0.145 \\
\hline & $(0.109)$ & $(0.106)$ & $(0.124)$ & $(0.102)$ & $(0.138)$ \\
\hline \multirow[t]{2}{*}{ Medium-tech manufacturing (d) } & 0.031 & 0.171 & 0.154 & 0.026 & 0.129 \\
\hline & $(0.112)$ & $(0.108)$ & $(0.131)$ & $(0.107)$ & $(0.140)$ \\
\hline \multirow[t]{2}{*}{ High-tech manufacturing (d) } & 0.023 & 0.183 & $0.479 * * *$ & -0.083 & 0.202 \\
\hline & $(0.147)$ & $(0.140)$ & $(0.158)$ & $(0.136)$ & $(0.188)$ \\
\hline \multirow[t]{2}{*}{ Constant } & $-1.089 * * *$ & $-1.746^{* * *}$ & $-1.656^{* * *}$ & $-0.727 * * *$ & 0.011 \\
\hline & $(0.199)$ & $(0.206)$ & $(0.233)$ & $(0.177)$ & $(0.214)$ \\
\hline Pseudo R2 & 0.21 & 0.13 & 0.08 & 0.08 & 0.11 \\
\hline $\mathrm{N}$ & 833 & 833 & 833 & 833 & 833 \\
\hline LR/Wald chi2 & 196.581 & 118.767 & 50.472 & 89.994 & 71.618 \\
\hline P-value & 0.00 & 0.00 & 0.00 & 0.00 & 0.00 \\
\hline Log likelihood & -443.143 & -478.102 & -328.488 & -519.815 & -285.775 \\
\hline
\end{tabular}


Table 5: Initiation of university-industry collaboration: Probit regression results for small versus large firms

\begin{tabular}{|c|c|c|c|c|c|c|c|c|c|c|}
\hline & \multicolumn{5}{|c|}{ Small firms $(n=521)$} & \multicolumn{5}{|c|}{ Large firms $(\mathrm{n}=312)$} \\
\hline & $\begin{array}{l}\text { Joint } \\
\text { research }\end{array}$ & $\begin{array}{l}\text { Contract } \\
\text { research }\end{array}$ & $\begin{array}{l}\text { In- } \\
\text { licensing }\end{array}$ & Consulting & $\begin{array}{l}\text { Informal } \\
\text { contacts }\end{array}$ & $\begin{array}{l}\text { Joint } \\
\text { research }\end{array}$ & $\begin{array}{l}\text { Contract } \\
\text { research }\end{array}$ & $\begin{array}{l}\text { In- } \\
\text { licensing }\end{array}$ & Consulting & $\begin{array}{l}\text { Informal } \\
\text { contacts }\end{array}$ \\
\hline Initiated by firm employees (d) & $\begin{array}{l}0.086 \\
(0.146)\end{array}$ & $\begin{array}{l}-0.049 \\
(0.145)\end{array}$ & $\begin{array}{l}-0.169 \\
(0.170)\end{array}$ & $\begin{array}{l}0.307^{* *} \\
(0.134)\end{array}$ & $\begin{array}{l}0.697 * * * \\
(0.154)\end{array}$ & $\begin{array}{l}0.469 * \\
(0.255)\end{array}$ & $\begin{array}{l}0.313 \\
(0.237)\end{array}$ & $\begin{array}{l}0.278 \\
(0.302)\end{array}$ & $\begin{array}{l}0.791 * * * \\
(0.223)\end{array}$ & $\begin{array}{l}0.870^{* * *} \\
(0.257)\end{array}$ \\
\hline Initiated by university scientists (d) & $\begin{array}{l}0.558 * * * \\
(0.151)\end{array}$ & $\begin{array}{l}0.405^{* * * *} \\
(0.143)\end{array}$ & $\begin{array}{l}0.218 \\
(0.169)\end{array}$ & $\begin{array}{l}0.251^{*} \\
(0.143)\end{array}$ & $\begin{array}{l}0.588 * * * \\
(0.203)\end{array}$ & $\begin{array}{l}0.201 \\
(0.192)\end{array}$ & $\begin{array}{l}0.481 * * * \\
(0.184)\end{array}$ & $\begin{array}{l}0.032 \\
(0.209)\end{array}$ & $\begin{array}{l}0.471 * * \\
(0.192)\end{array}$ & $\begin{array}{l}0.405 \\
(0.283)\end{array}$ \\
\hline Initiated by university TTO (d) & $\begin{array}{l}0.245 \\
(0.220)\end{array}$ & $\begin{array}{l}0.289 \\
(0.201)\end{array}$ & $\begin{array}{l}0.155 \\
(0.235)\end{array}$ & $\begin{array}{l}0.421^{* *} \\
(0.205)\end{array}$ & $\begin{array}{l}0.157 \\
(0.288)\end{array}$ & $\begin{array}{l}0.284 \\
(0.232)\end{array}$ & $\begin{array}{l}0.126 \\
(0.222)\end{array}$ & $\begin{array}{l}0.258 \\
(0.228)\end{array}$ & $\begin{array}{l}0.684 * * * \\
(0.242)\end{array}$ & $\begin{array}{l}-0.013 \\
(0.368)\end{array}$ \\
\hline Patent stock per employee & $\begin{array}{l}0.056 \\
(0.330)\end{array}$ & $\begin{array}{l}-0.573^{*} \\
(0.344)\end{array}$ & $\begin{array}{l}-1.313 \\
(1.606)\end{array}$ & $\begin{array}{l}-0.184 \\
(0.422)\end{array}$ & $\begin{array}{l}4.578 \\
(3.872)\end{array}$ & $\begin{array}{l}-2.151 \\
(3.038)\end{array}$ & $\begin{array}{l}-2.334 \\
(3.057)\end{array}$ & $\begin{array}{l}-2.757 \\
(3.081)\end{array}$ & $\begin{array}{l}0.576 \\
(3.529)\end{array}$ & $\begin{array}{l}-2.072 \\
(5.230)\end{array}$ \\
\hline R\&D per employee & $\begin{array}{l}1.149 \\
(1.582)\end{array}$ & $\begin{array}{l}5.590 * * * \\
(2.092)\end{array}$ & $\begin{array}{l}5.105 * * * \\
(1.862)\end{array}$ & $\begin{array}{l}0.656 \\
(1.573)\end{array}$ & $\begin{array}{l}1.4 \\
(3.458)\end{array}$ & $\begin{array}{l}0.122 \\
(5.125)\end{array}$ & $\begin{array}{l}-0.099 \\
(3.975)\end{array}$ & $\begin{array}{l}4.261 \\
(3.837)\end{array}$ & $\begin{array}{l}-2.073 \\
(4.027)\end{array}$ & $\begin{array}{l}26.026 * * \\
(12.627)\end{array}$ \\
\hline Strategy: technology leadership (d) & $\begin{array}{l}0.174 \\
(0.139)\end{array}$ & $\begin{array}{l}0.053 \\
(0.137)\end{array}$ & $\begin{array}{l}-0.127 \\
(0.164)\end{array}$ & $\begin{array}{l}0.029 \\
(0.130)\end{array}$ & $\begin{array}{l}-0.015 \\
(0.166)\end{array}$ & $\begin{array}{l}0.248 \\
(0.165)\end{array}$ & $\begin{array}{l}0.359 * * \\
(0.160)\end{array}$ & $\begin{array}{l}0.12 \\
(0.183)\end{array}$ & $\begin{array}{l}0.262 \\
(0.164)\end{array}$ & $\begin{array}{l}0.543^{* *} \\
(0.237)\end{array}$ \\
\hline State funding (d) & $\begin{array}{l}0.372 * * \\
(0.151)\end{array}$ & $\begin{array}{l}0.292^{* *} \\
(0.146)\end{array}$ & $\begin{array}{l}0.23 \\
(0.172)\end{array}$ & $\begin{array}{l}0.179 \\
(0.141)\end{array}$ & $\begin{array}{l}0.229 \\
(0.203)\end{array}$ & $\begin{array}{l}0.291 \\
(0.236)\end{array}$ & $\begin{array}{l}0.423^{*} \\
(0.221)\end{array}$ & $\begin{array}{l}0.02 \\
(0.219)\end{array}$ & $\begin{array}{l}0.21 \\
(0.222)\end{array}$ & $\begin{array}{l}0.093 \\
(0.367)\end{array}$ \\
\hline Federal funding (d) & $\begin{array}{l}0.882 * * * \\
(0.146)\end{array}$ & $\begin{array}{l}0.206 \\
(0.147)\end{array}$ & $\begin{array}{l}0.024 \\
(0.174)\end{array}$ & $\begin{array}{l}0.334^{* *} \\
(0.143)\end{array}$ & $\begin{array}{l}0.232 \\
(0.199)\end{array}$ & $\begin{array}{l}1.078 * * * \\
(0.195)\end{array}$ & $\begin{array}{l}0.455^{* *} \\
(0.192)\end{array}$ & $\begin{array}{l}0.417^{* *} \\
(0.208)\end{array}$ & $\begin{array}{l}-0.034 \\
(0.194)\end{array}$ & $\begin{array}{l}0.122 \\
(0.316)\end{array}$ \\
\hline EU funding (d) & $\begin{array}{l}0.438 * * \\
(0.215)\end{array}$ & $\begin{array}{l}-0.062 \\
(0.204)\end{array}$ & $\begin{array}{l}0.125 \\
(0.235)\end{array}$ & $\begin{array}{l}-0.032 \\
(0.203)\end{array}$ & $\begin{array}{l}-0.164 \\
(0.285)\end{array}$ & $\begin{array}{l}0.125 \\
(0.242)\end{array}$ & $\begin{array}{l}0.065 \\
(0.234)\end{array}$ & $\begin{array}{l}-0.467 * \\
(0.282)\end{array}$ & $\begin{array}{l}0.222 \\
(0.249)\end{array}$ & $\begin{array}{l}0.324 \\
(0.443)\end{array}$ \\
\hline No of employees (log) & $\begin{array}{l}-0.031 \\
(0.061)\end{array}$ & $\begin{array}{l}0.031 \\
(0.063)\end{array}$ & $\begin{array}{l}-0.016 \\
(0.073)\end{array}$ & $\begin{array}{l}-0.034 \\
(0.056)\end{array}$ & $\begin{array}{l}0.048 \\
(0.076)\end{array}$ & $\begin{array}{l}0.049 \\
(0.076)\end{array}$ & $\begin{array}{l}0.09 \\
(0.086)\end{array}$ & $\begin{array}{l}0.192 * * \\
(0.078)\end{array}$ & $\begin{array}{l}0.074 \\
(0.076)\end{array}$ & $\begin{array}{l}0.333^{* *} \\
(0.151)\end{array}$ \\
\hline Location East Germany (d) & $\begin{array}{l}-0.132 \\
(0.137)\end{array}$ & $\begin{array}{l}-0.075 \\
(0.131)\end{array}$ & $\begin{array}{l}-0.306^{*} \\
(0.162)\end{array}$ & $\begin{array}{l}-0.072 \\
(0.123)\end{array}$ & $\begin{array}{l}-0.007 \\
(0.151)\end{array}$ & $\begin{array}{l}-0.348 \\
(0.232)\end{array}$ & $\begin{array}{l}0.08 \\
(0.216)\end{array}$ & $\begin{array}{l}-0.205 \\
(0.252)\end{array}$ & $\begin{array}{l}0.353 \\
(0.227)\end{array}$ & $\begin{array}{l}0.312 \\
(0.308)\end{array}$ \\
\hline Part of group (d) & $\begin{array}{l}-0.188 \\
(0.151)\end{array}$ & $\begin{array}{l}-0.015 \\
(0.144)\end{array}$ & $\begin{array}{l}0.024 \\
(0.169)\end{array}$ & $\begin{array}{l}0.029 \\
(0.133)\end{array}$ & $\begin{array}{l}-0.297 * \\
(0.169)\end{array}$ & $\begin{array}{l}0.372 * * \\
(0.184)\end{array}$ & $\begin{array}{l}0.139 \\
(0.178)\end{array}$ & $\begin{array}{l}0.016 \\
(0.212)\end{array}$ & $\begin{array}{l}-0.17 \\
(0.180)\end{array}$ & $\begin{array}{l}0.083 \\
(0.231)\end{array}$ \\
\hline Medium-tech manufacturing (d) & $\begin{array}{l}0.163 \\
(0.150)\end{array}$ & $\begin{array}{l}0.193 \\
(0.147)\end{array}$ & $\begin{array}{l}-0.046 \\
(0.187)\end{array}$ & $\begin{array}{l}0.011 \\
(0.139)\end{array}$ & $\begin{array}{l}0.139 \\
(0.175)\end{array}$ & $\begin{array}{l}-0.117 \\
(0.185)\end{array}$ & $\begin{array}{l}0.23 \\
(0.174)\end{array}$ & $\begin{array}{l}0.351 * \\
(0.195)\end{array}$ & $\begin{array}{l}-0.05 \\
(0.176)\end{array}$ & $\begin{array}{l}-0.056 \\
(0.249)\end{array}$ \\
\hline High-tech manufacturing (d) & $\begin{array}{l}0.087 \\
(0.175)\end{array}$ & $\begin{array}{l}0.124 \\
(0.173)\end{array}$ & $\begin{array}{l}0.276 \\
(0.198)\end{array}$ & $\begin{array}{l}-0.212 \\
(0.162)\end{array}$ & $\begin{array}{l}0.095 \\
(0.215)\end{array}$ & $\begin{array}{l}-0.181 \\
(0.293)\end{array}$ & $\begin{array}{l}0.369 \\
(0.260)\end{array}$ & $\begin{array}{l}0.851^{* * * *} \\
(0.266)\end{array}$ & $\begin{array}{l}-0.086 \\
(0.280)\end{array}$ & $\begin{array}{l}-0.169 \\
(0.449)\end{array}$ \\
\hline Constant & $\begin{array}{l}-0.929 * * * \\
(0.276)\end{array}$ & $\begin{array}{l}-1.100^{* * *} \\
(0.280)\end{array}$ & $\begin{array}{l}-1.072^{* * *} \\
(0.318)\end{array}$ & $\begin{array}{l}-0.218 \\
(0.245)\end{array}$ & $\begin{array}{l}0.216 \\
(0.314)\end{array}$ & $\begin{array}{l}-1.777^{* * *} \\
(0.560)\end{array}$ & $\begin{array}{l}-1.749^{* * *} \\
(0.580)\end{array}$ & $\begin{array}{l}-2.956^{* * *} \\
(0.660)\end{array}$ & $\begin{array}{l}-1.101^{* *} \\
(0.539)\end{array}$ & $\begin{array}{l}-2.183^{* *} \\
(0.999)\end{array}$ \\
\hline Pseudo R2 & 0.22 & 0.08 & 0.06 & 0.05 & 0.13 & 0.23 & 0.16 & 0.13 & 0.14 & 0.24 \\
\hline LR/Wald chi2 & 131.545 & 46.193 & 28.44 & 37.645 & 55.024 & 81.284 & 62.373 & 34.568 & 54.166 & 39.696 \\
\hline P-value & 0 & 0 & 0.012 & 0.001 & 0 & 0 & 0 & 0.002 & 0 & 0 \\
\hline Log likelihood & -270.724 & -286.499 & -189.259 & -340.846 & -188.249 & -164.266 & -180.701 & -132.178 & -173.798 & -78.456 \\
\hline
\end{tabular}


Table 6: Management of university-industry collaboration: Probit regression results for small versus large firms

\begin{tabular}{|c|c|c|c|c|c|c|c|c|c|c|}
\hline & \multicolumn{5}{|c|}{ Small firms $(n=521)$} & \multicolumn{5}{|c|}{ Large firms $(\mathrm{n}=312)$} \\
\hline & $\begin{array}{l}\text { Joint } \\
\text { research }\end{array}$ & $\begin{array}{l}\text { Contract } \\
\text { research }\end{array}$ & $\begin{array}{l}\text { In- } \\
\text { licensing }\end{array}$ & Consulting & $\begin{array}{l}\text { Informal } \\
\text { contacts }\end{array}$ & $\begin{array}{l}\text { Joint } \\
\text { research }\end{array}$ & $\begin{array}{l}\text { Contract } \\
\text { research }\end{array}$ & $\begin{array}{l}\text { In- } \\
\text { licensing }\end{array}$ & Consulting & $\begin{array}{l}\text { Informal } \\
\text { contacts }\end{array}$ \\
\hline Managed by firm employees (d) & $\begin{array}{c}0.351^{* *} \\
(0.158)\end{array}$ & $\begin{array}{c}0.305^{* *} \\
(0.155)\end{array}$ & $\begin{array}{l}-0.155 \\
(0.172)\end{array}$ & $\begin{array}{l}0.397 * * * \\
(0.138)\end{array}$ & $\begin{array}{c}0.360^{* *} \\
(0.153)\end{array}$ & $\begin{array}{l}0.216 \\
(0.259)\end{array}$ & $\begin{array}{l}0.137 \\
(0.235)\end{array}$ & $\begin{array}{l}0.358 \\
(0.323)\end{array}$ & $\begin{array}{l}0.520^{* *} \\
(0.236)\end{array}$ & $\begin{array}{c}0.506^{*} \\
(0.259)\end{array}$ \\
\hline Managed by university scientists (d) & $\begin{array}{l}0.440^{* * *} \\
(0.142)\end{array}$ & $\begin{array}{c}0.245 * \\
(0.140)\end{array}$ & $\begin{array}{c}0.388^{* *} \\
(0.160)\end{array}$ & $\begin{array}{c}0.347^{* *} \\
(0.139)\end{array}$ & $\begin{array}{c}0.436^{* *} \\
(0.183)\end{array}$ & $\begin{array}{l}0.216 \\
(0.176)\end{array}$ & $\begin{array}{l}0.458^{* * * *} \\
(0.174)\end{array}$ & $\begin{array}{l}0.179 \\
(0.200)\end{array}$ & $\begin{array}{l}0.658^{* * *} \\
(0.181)\end{array}$ & $\begin{array}{c}0.579 * \\
(0.299)\end{array}$ \\
\hline Managed by university TTO (d) & $\begin{array}{l}0.282 \\
(0.201)\end{array}$ & $\begin{array}{l}0.1 \\
(0.198)\end{array}$ & $\begin{array}{l}-0.256 \\
(0.237)\end{array}$ & $\begin{array}{l}0.379 * * \\
(0.191)\end{array}$ & $\begin{array}{l}0.017 \\
(0.233)\end{array}$ & $\begin{array}{l}0.241 \\
(0.245)\end{array}$ & $\begin{array}{l}-0.057 \\
(0.227)\end{array}$ & $\begin{array}{l}0.211 \\
(0.279)\end{array}$ & $\begin{array}{l}0.31 \\
(0.248)\end{array}$ & $\begin{array}{l}0.455 \\
(0.434)\end{array}$ \\
\hline Patent stock per employee & $\begin{array}{l}0.011 \\
(0.326)\end{array}$ & $\begin{array}{l}-0.623^{*} \\
(0.351)\end{array}$ & $\begin{array}{l}-1.48 \\
(1.463)\end{array}$ & $\begin{array}{l}-0.146 \\
(0.435)\end{array}$ & $\begin{array}{l}3.799 \\
(3.372)\end{array}$ & $\begin{array}{l}-1.415 \\
(2.934)\end{array}$ & $\begin{array}{l}-0.862 \\
(3.007)\end{array}$ & $\begin{array}{l}-2.35 \\
(3.006)\end{array}$ & $\begin{array}{l}2.526 \\
(3.495)\end{array}$ & $\begin{array}{l}-0.492 \\
(6.112)\end{array}$ \\
\hline R\&D per employee & $\begin{array}{l}0.317 \\
(1.624)\end{array}$ & $\begin{array}{l}5.292 * * \\
(2.104)\end{array}$ & $\begin{array}{l}5.041 \text { *** } \\
(1.916)\end{array}$ & $\begin{array}{l}-0.151 \\
(1.695)\end{array}$ & $\begin{array}{l}1.428 \\
(4.007)\end{array}$ & $\begin{array}{l}-1.191 \\
(5.329)\end{array}$ & $\begin{array}{l}-1.739 \\
(3.924)\end{array}$ & $\begin{array}{l}3.344 \\
(3.723)\end{array}$ & $\begin{array}{l}-6.08 \\
(3.901)\end{array}$ & $\begin{array}{l}12.304 \\
(13.452)\end{array}$ \\
\hline Strategy: technology leadership (d) & $\begin{array}{l}0.189 \\
(0.138)\end{array}$ & $\begin{array}{l}0.064 \\
(0.136)\end{array}$ & $\begin{array}{l}-0.166 \\
(0.162)\end{array}$ & $\begin{array}{l}0.057 \\
(0.131)\end{array}$ & $\begin{array}{l}0.044 \\
(0.163)\end{array}$ & $\begin{array}{l}0.23 \\
(0.168)\end{array}$ & $\begin{array}{c}0.332^{* *} \\
(0.162)\end{array}$ & $\begin{array}{l}0.084 \\
(0.184)\end{array}$ & $\begin{array}{l}0.223 \\
(0.167)\end{array}$ & $\begin{array}{l}0.557^{* *} \\
(0.248)\end{array}$ \\
\hline State funding (d) & $\begin{array}{c}0.394^{* * *} \\
(0.148)\end{array}$ & $\begin{array}{c}0.315^{* *} \\
(0.145)\end{array}$ & $\begin{array}{l}0.266 \\
(0.171)\end{array}$ & $\begin{array}{l}0.182 \\
(0.139)\end{array}$ & $\begin{array}{l}0.268 \\
(0.194)\end{array}$ & $\begin{array}{l}0.238 \\
(0.230)\end{array}$ & $\begin{array}{c}0.385 * \\
(0.218)\end{array}$ & $\begin{array}{l}-0.01 \\
(0.229)\end{array}$ & $\begin{array}{l}0.11 \\
(0.230)\end{array}$ & $\begin{array}{l}0.203 \\
(0.401)\end{array}$ \\
\hline Federal funding (d) & $\begin{array}{l}0.847 * * * \\
(0.145)\end{array}$ & $\begin{array}{l}0.192 \\
(0.146)\end{array}$ & $\begin{array}{l}0.012 \\
(0.173)\end{array}$ & $\begin{array}{c}0.288^{* *} \\
(0.144)\end{array}$ & $\begin{array}{l}0.225 \\
(0.198)\end{array}$ & $\begin{array}{l}1.050^{* * *} \\
(0.195)\end{array}$ & $\begin{array}{c}0.412^{* *} \\
(0.190)\end{array}$ & $\begin{array}{c}0.405 * \\
(0.208)\end{array}$ & $\begin{array}{l}-0.091 \\
(0.202)\end{array}$ & $\begin{array}{l}-0.081 \\
(0.331)\end{array}$ \\
\hline EU funding (d) & $\begin{array}{c}0.482^{* *} \\
(0.214)\end{array}$ & $\begin{array}{l}-0.044 \\
(0.202)\end{array}$ & $\begin{array}{l}0.121 \\
(0.232)\end{array}$ & $\begin{array}{l}0.015 \\
(0.208)\end{array}$ & $\begin{array}{l}-0.083 \\
(0.288)\end{array}$ & $\begin{array}{l}0.14 \\
(0.243)\end{array}$ & $\begin{array}{l}0.099 \\
(0.241)\end{array}$ & $\begin{array}{l}-0.485^{*} \\
(0.292)\end{array}$ & $\begin{array}{l}0.237 \\
(0.245)\end{array}$ & $\begin{array}{l}0.319 \\
(0.464)\end{array}$ \\
\hline No of employees (log) & $\begin{array}{l}-0.048 \\
(0.063)\end{array}$ & $\begin{array}{l}0.019 \\
(0.063)\end{array}$ & $\begin{array}{l}-0.005 \\
(0.072)\end{array}$ & $\begin{array}{l}-0.04 \\
(0.057)\end{array}$ & $\begin{array}{l}0.055 \\
(0.070)\end{array}$ & $\begin{array}{l}0.085 \\
(0.075)\end{array}$ & $\begin{array}{l}0.124 \\
(0.083)\end{array}$ & $\begin{array}{l}0.200 * * * \\
(0.076)\end{array}$ & $\begin{array}{l}0.13 \\
(0.081)\end{array}$ & $\begin{array}{l}0.405^{* * *} \\
(0.153)\end{array}$ \\
\hline Location East Germany (d) & $\begin{array}{l}-0.096 \\
(0.139)\end{array}$ & $\begin{array}{l}-0.064 \\
(0.132)\end{array}$ & $\begin{array}{l}-0.334^{* *} \\
(0.163)\end{array}$ & $\begin{array}{l}-0.012 \\
(0.123)\end{array}$ & $\begin{array}{l}0.063 \\
(0.150)\end{array}$ & $\begin{array}{l}-0.347 \\
(0.237)\end{array}$ & $\begin{array}{l}0.036 \\
(0.222)\end{array}$ & $\begin{array}{l}-0.216 \\
(0.260)\end{array}$ & $\begin{array}{l}0.31 \\
(0.222)\end{array}$ & $\begin{array}{l}0.255 \\
(0.323)\end{array}$ \\
\hline Part of group (d) & $\begin{array}{l}-0.148 \\
(0.149)\end{array}$ & $\begin{array}{l}0.001 \\
(0.142)\end{array}$ & $\begin{array}{l}0.009 \\
(0.168)\end{array}$ & $\begin{array}{l}0.073 \\
(0.132)\end{array}$ & $\begin{array}{l}-0.221 \\
(0.159)\end{array}$ & $\begin{array}{l}0.403^{* *} \\
(0.178)\end{array}$ & $\begin{array}{l}0.191 \\
(0.177)\end{array}$ & $\begin{array}{l}0.028 \\
(0.211)\end{array}$ & $\begin{array}{l}-0.051 \\
(0.173)\end{array}$ & $\begin{array}{l}0.152 \\
(0.229)\end{array}$ \\
\hline Medium-tech manufacturing (d) & $\begin{array}{l}0.135 \\
(0.149)\end{array}$ & $\begin{array}{l}0.167 \\
(0.147)\end{array}$ & $\begin{array}{l}-0.032 \\
(0.185)\end{array}$ & $\begin{array}{l}-0.01 \\
(0.139)\end{array}$ & $\begin{array}{l}0.154 \\
(0.173)\end{array}$ & $\begin{array}{l}-0.068 \\
(0.182)\end{array}$ & $\begin{array}{l}0.258 \\
(0.171)\end{array}$ & $\begin{array}{c}0.398 * * \\
(0.189)\end{array}$ & $\begin{array}{l}0.053 \\
(0.175)\end{array}$ & $\begin{array}{l}0.109 \\
(0.239)\end{array}$ \\
\hline High-tech manufacturing (d) & $\begin{array}{l}0.084 \\
(0.174)\end{array}$ & $\begin{array}{l}0.112 \\
(0.171)\end{array}$ & $\begin{array}{l}0.278 \\
(0.197)\end{array}$ & $\begin{array}{l}-0.203 \\
(0.162)\end{array}$ & $\begin{array}{l}0.177 \\
(0.206)\end{array}$ & $\begin{array}{l}-0.104 \\
(0.301)\end{array}$ & $\begin{array}{c}0.436^{*} \\
(0.263)\end{array}$ & $\begin{array}{l}0.921^{* * *} \\
(0.271)\end{array}$ & $\begin{array}{l}0.191 \\
(0.272)\end{array}$ & $\begin{array}{l}0.222 \\
(0.469)\end{array}$ \\
\hline Constant & $\begin{array}{l}-1.067^{* * *} \\
(0.296)\end{array}$ & $\begin{array}{l}-1.271^{* * *} \\
(0.289)\end{array}$ & $\begin{array}{l}-1.108^{* * *} \\
(0.326)\end{array}$ & $\begin{array}{l}-0.329 \\
(0.254)\end{array}$ & $\begin{array}{l}0.296 \\
(0.299)\end{array}$ & $\begin{array}{l}-1.849 * * * \\
(0.559)\end{array}$ & $\begin{array}{l}-1.850^{* * *} \\
(0.605)\end{array}$ & $\begin{array}{l}-3.142 * * * \\
(0.599)\end{array}$ & $\begin{array}{l}-1.392^{* * *} \\
(0.583)\end{array}$ & $\begin{array}{l}-2.526^{* *} \\
(1.019)\end{array}$ \\
\hline Pseudo R2 & 0.22 & 0.08 & 0.07 & 0.06 & 0.08 & 0.22 & 0.16 & 0.14 & 0.13 & 0.23 \\
\hline LR/Wald chi2 & 129.721 & 44.467 & 29.621 & 41.871 & 31.87 & 75.286 & 58.135 & 42.005 & 55.832 & 35.337 \\
\hline P-value & 0 & 0 & 0.009 & 0 & 0.004 & 0 & 0 & 0 & 0 & 0.001 \\
\hline Log likelihood & -270.059 & -288.141 & -187.893 & -337.259 & -198.832 & -166.3 & -182.044 & -131.5 & -176.539 & -79.59 \\
\hline
\end{tabular}

